\title{
Financing Social Enterprise in the very long run
}

\author{
Jeremy Thornton ${ }^{1}$ \\ Samford University \\ David King ${ }^{2}$ \\ Indiana University-Purdue University Indianapolis
}

\begin{abstract}
Social enterprises share a common struggle to finance output that have public good characteristics. Public goods are notoriously difficult for private firms to produce, because of the incentive for their constituents to defect, or free-ride, on the contributions of others. Due of their historical success, this paper examines long-lived religions institutions for strategies to mitigate this collective action problem. We empirically examine the Southern Baptist Convention, which records its efforts to finance international mission activities since 1935 . We test a variation of the club good model, which emphasizes imposing costs on members to separate out high intensity adherents. Consistent with the model, we find that contributions to international missions increase when the cost of affiliation increases. We do not find that the specific mechanism for collection within the Southern Baptist matters. We conclude that the club model of organization, where high membership costs are deliberately applied, offers valuable - and counterintuitive -lessons for social enterprises more broadly.
\end{abstract}

JEL: H41, Z12, D2, L3

Keywords: Social Entrepreneurship, Finance, Religion, Club Model

\footnotetext{
${ }^{1}$ Professor of Economics and Dwight Moody Beeson Chair of Business Brock School of Business, Birmingham, AL USA 35229 jpthornt@samford.edu (Contact Author)

${ }^{2}$ Assistant Professor, Karen Lake Buttery Director, Lake Institute for Faith and Giving Lilly Family School of Philanthropy, Indianapolis, IN USA 46202 kingdp@iupui.edu
} 


\section{Introduction}

This paper examines techniques available to finance social enterprise over very long time horizons. We adopt a model of social enterprise described in Santos (Santos, 2012), where the distinctive characteristic of social entrepreneurship is the private production of public goods (or, the more modern term - collective goods). ${ }^{1}$ In contrast to the existing literature, Santos (2012) explores a non-normative definition of a social entrepreneur, where "social" implies deliberate strategy to produce a positive externality, or public good. Public goods are classically identified by their absence, to varying degrees, of rivalry and excludablity. These characteristics describe the circumstance where consumption by one individual does not preclude the consumption by others, nor can non-contributors be excluded from consumption (Mas-Colell, Whinston, \& Green, 1995, p. 359).

Examples of public goods in the social entrepreneurship literature may include: cultural goods production; environmental protection, public health, or anti-poverty programs (Elkington \& Hartigan, 2008). ${ }^{2}$ Importantly, even if a wide range of consumers value the public good, each individual has a private incentive to free-ride on the contributions of others, rather than contribute themselves (Varian, 2014, p. 717). Collectively, the production of the public good will be sub-optimal because no individual accounts for the public good's value to others in their contribution (Cornes \& Sandler, 1996, Chapter 6). Overcoming

\footnotetext{
${ }^{1}$ Santos (2012) uses the language of value creation and value capture to make the distinction between social entrepreneurs and traditional profit maximizing firms. $\mathrm{He}$ rejects the distinction between social and economic value creation, thereby allowing for a concrete definition of social value (p.337). The profit maximizing firm sets a strategy to capture as much value from a transaction as possible. In contrast, Santos argues that the social entrepreneur seeks to maximise value creation (p.337). While Santos emphasizes consumer surplus, there is no good reason to discount the value accrued to producers, particularly the suppliers of productive inputs. Value creation in excess of that which is captured by parties in the transaction is described by economists as an externality. Public (or collective) goods refer to the circumstance where externalities are shared among more than two or more economic agents. In this case, public goods must be provided in the same amount to all consumers, regardless of their valuation of the good.

2 Cornes and Sandler (1996) use the term "easy rider" for the more common circumstance where crowd-out is incomplete (p.455).
} 
free riding behavior when financing the production of public goods is a key constraint to designing a successful social enterprise business model.

The challenges associated with financing public goods have been thoroughly examined in the social sciences. Theory, supported by extensive experimental research, demonstrates the difficulty in sustaining voluntary cooperative networks to produce public goods (Andreoni, 1988; Andreoni \& Payne, 2013; Bergstrom, Blume, \& Varian, 1986; Dawes \& Thaler, 1988; James Andreoni \& A. Abigail Payne, 2008).

This paper contributes to the social enterprise literature by examining the methods used by long-lived institutions to sustain collective contributions to a public good. We test a specific variant of the club model for public goods production (Iannaccone, 1992). We confirm the models basic intuition, where imposing a high cost to deter low value members can - under certain conditions - reduce free riding. Exclusion of low-value members can induce sustainable contributions to the public good by creating a separating equilibrium, where only those who sufficiently value the good will choose to participate in the club. We discuss the circumstances where this strategy may be appropriate for social entrepreneurs.

The paper begins with an overview of existing financing schemes for public goods. The paper then narrows its scope to examine the particular strategies applied by religiously motivated institutions who also choose to produce locally public goods. The paper is careful to explain how the study of religiously motivated institutions may inform financing strategies for social enterprise more broadly. The paper then tests several hypotheses drawn from the club model in the context of religious production. Finally, we connect our findings to common challenges faced by social enterprises. 


\section{Typology of financing collective goods}

Public goods are notoriously difficult to finance. Economic theory predicts that, when a good (or service) are both nonrival and nonexculable, the dominant strategy for any individual contributor is to "free ride" on the contributions of others (Andreoni, 1988; Dawes \& Thaler, 1988; Fischbacher \& Gächter, 2010). For exposition purposes, we sketch a brief canonical model. ${ }^{3}$

An individual $i$ receives utility from both a private good $\mathrm{y}_{\mathrm{i}}$ and the total value of a public good $X=\sum_{i=1}^{n} x_{i}$, where $U_{i}\left(y_{i}, X\right)$ is continuous, strictly increasing, and twice differentiable. Importantly, $\mathrm{X}$ has standard public good characteristics, such that it is both nonrival and non-excludable. Thus, agent $i$ takes the value of $\mathrm{X}$ as exogenous. Maximizing utility by the representative consumer results in the socially optimal condition:

$$
\sum_{i=1}^{n} M R S_{y_{i} X}=M C_{X}
$$

Which notes that the optimal quantity of the public good equates the sum of the marginal rates of substitution for $\mathrm{X}$ to its cost (i.e. the Samuelson condition). However, each individual will choose to maximize:

$$
\max U\left(y_{i}, x_{i}+X_{-i}\right)
$$

Where individual I will choose:

$$
M R S_{y_{i} x_{i}}=M C_{X}
$$

\footnotetext{
${ }^{3}$ Adapted from Cornes \& Sandler (1996)
} 
Because each individual may consume $\mathrm{X}_{-i}$ and takes its value as given, only individual $i$ with the highest value of $\mathrm{X}$ will contribute anything to the public good. Others will simply free-ride on that individual's contribution, and increase their consumption of the private good. Consequently, the public good will be provided in a socially insufficient quantity.

A common example is street lamps for a neighbourhood. Because everyone in the neighbourhood benefits from the street lamps, the best strategy for any one household is to allow other households to contribute, while they themselves defect. Unfortunately, this is the dominant strategy for each household, resulting in sub-optimal lighting, even if streetlights are highly valued. Thus, private markets, which attempt to charge positive prices for use of the streetlights, often fail, because individuals will consume the good regardless.

In a social entrepreneurship context, reductions of global poverty, public safety, improved environmental conditions, or better educational opportunities each have public good traits. Individuals may easily "consume" these goods without diminishing the consumption of others, even if they have not contributed. As everyone faces a similar incentive, it becomes difficult to finance the good's production. How then can a social enterprise form a sustainable business model to finance the production of public goods? There are generally three broad strategies.

\section{Government (Public) Provision}

The most straightforward method of providing collective goods is for government to finance them. Governments can mitigate the freerider problem by compelling payment through a system of taxation. Government agencies can either provide the collective good directly (as with a standing military or Global Positioning System satellites), or they can contract with private agencies to produce the service (as with foster care or private prisons). Government agencies are not the only institutions with the power to compel payments. Private community organizations such as homeowners associations, unions, and social clubs 
may operate (often with the explicit or implicit backing of the government) in a similar way.

Academic inquiry into the public financing of collective goods has produced an extensive literature dating back to mid twentieth century (Samuelson, 1954). European countries have typically followed a model of more direct public support for social enterprise, relative to the US (Defourny \& Nyssens, 2010). Even so, approximately one-third of revenues for the US non-profit sector are derived from government funding (McKeever, 2015).

However, financing collective goods through government taxation poses its own problems. The most well-known is the incidence of deadweight loss generated by the taxation necessary for public funding (Hausman, 1981). Depending on the form of the tax, government intervention may lead to losses in consumer and producer surplus by preventing mutually beneficial transactions that would have been consummated absent the tax. Second, the government agency must decide how much, or little, of the public good to provide (Manning et al., 1985). Should a state have more or less vocational training, public healthcare, or child literacy programs? Voting mechanisms are notoriously imprecise aggregating citizen preferences, resulting in allocative inefficiency (Gruber, 2005, pp. 228-230).

\section{Financing Public Goods from Residual Profits}

A second alternative is for private firms to divert residual revenues from other business lines to finance public goods. One technique is to embed an implicit contribution in the price of a private good. TOMS shoes and fair trade coffee fall under this model. Consumers understand that they are paying a significant premium over the firm's cost in order to provide an implicit donation to a particular cause. Consumers buy a pair of shoes, eyeglasses, or coffee and a portion of these revenues is used to finance charitable (public good) output. The approach has proven successful at raising revenue, and has thus been mimicked by a variety of organisations such as Mealshare, Two Degrees, and Nouri (Marquis \& Park, 2014). 
Alternatively, firms may finance the public good output indirectly via a diversion of residual profits from unrelated business lines. This type of indirect financing is more common for large corporations, and often conducted under the label of corporate social responsibility (CSR). These charitable expenditures may be related to the firm's core business, as in Coca Cola's water stewardship program. Others, such as Walmart and Target, emphasize health and education, which are only tangentially related to their core business lines. See Aguinis and Glavas (2012) for a comprehensive review of this CSR research.

Unfortunately, the diversion of residual profits to the production of collective goods requires that there first be residual profits to allocate. Competitive market theory predicts that residual profits will be driven to zero in efficient markets, which are common for start-up stage businesses (Hamilton, 2000). Notably, this circumstance does not require competition solely from profit driven competitors. Even competition among like-minded social entrepreneurs can drive residual profits to zero (Bagnoli \& Watts, 2003). Sustaining a residual that can be applied to social mission requires a substantial degree of market power. Absent new technologies, government regulation, barriers to entry, or large economies of scale, market power is often transitory and difficult for a social entrepreneur to maintain.

\section{Voluntary Contributions}

Third, social enterprises may receive charitable contributions or subsidies directly from the public. Decentralized charitable contributions remain a dominant form of financing for the non-profit sector (Andreoni, 2006; Mckeever, 2015). It is also common for forprofit social entrepreneurs to operate with some type of donative income (ether as cash, in-kind donations, or volunteer labour) in its revenue mix (Austin, Stevenson, \& Wei-Skillern, 2006; Oster, 1995). Implicit donations may also come in the form of resources priced below their market rates (i.e. subsidized credit or tax incentives).

However, reliance on donation revenue also has significant limitations. Donors are not immune from the free rider problem. 
Donations from one individual may offset the gifts of another (Andreoni, 1990; Cornes \& Sandler, 1996). Just as significant, the fraction of national income allocated to explicit charitable giving has remained consistent over the past several decades (Mckeever, 2015). This implies that new entry into donor markets likely displaces incumbent charitable production.

\section{Another way? The club model}

Financing public goods out of residual revenues or through donations may be relatively common, however, neither are immune to the free rider problem discussed previously (Powell \& Steinberg, 2006). ${ }^{4}$ This paper, instead, will re-introduce a (perhaps) older technique to mitigate free riding. The club model of local public goods is an adaptation of the public goods model that may offer particular insights for financing certain types of social enterprise. Cornes \& Sandler (1996) list a few key traits that distinguish club goods from traditional public goods:

1. The (local) public goods are jointly provided by a club with a defined membership. Club goods are both nonrival and (typically) non-excludable within the club, but (partially) excludable to non-members.

2. Membership in the club is voluntary, thus the benefits of membership (consumption of the local public good) must exceed the cost of membership.

3. Both the benefits and costs of club membership vary with club size. Clubs may use some type of exclusion mechanism to manage club size.

The club model dates back to Buchanan (1965). The original application of the model was to help economist explain and analyze the behaviour of traditional health clubs, country clubs, homeowner

${ }^{4} \mathrm{CSR}$ and donation flows are also likely sensitive to tax regimes. See Kitzmueller \& Shimshack (2012) for a thorough review. 
associations, and the like. A key element of the club model is that the public good created and maintained by the club is congestible, meaning its usefulness declines with the total number of members. Thus, club members will develop an exclusion mechanism (such as a membership fee) to restrict usage of the local public good. However, there is a tradeoff. Fewer members imply higher per-person costs for each individual. The model identifies the trade-off between lowering the average cost per member and overuse of the public good.

Iannaccone (1992) later innovated on the club model to help explain how certain religious sects succeeded despite (or perhaps because of) the high levels of personal sacrifice required from their members. The innovation of the club model was to invert the concept of congestion. Now club members' utility increased with the active participation of others. Consistent with religious practice, adherents benefit when members actively participate, but are harmed by religious free riders. In this way, religious prohibitions (i.e. admonitions against alcohol consumption or certain sexual behaviours) serve as a tax on secular activity, thereby encouraging religious participation.

Berman $(2003 ; 2000 ; 2008)$ extends the Iannaconne model by demonstrating that personal sacrifice (i.e. significant contributions of time or money, strict dress codes, or even violence) can enhance the value of clubs by creating a separating equilibrium. By making club participation costly, only those who are sufficiently fervent will find it beneficial to participate in a religious club. Iannaccone (1992) spawned a significant literature in the application of clubs to a wide variety of religious and secular groups. ${ }^{5}$ We test the idea that social enterprise which may produce club style goods - can be analysed from this framework. To make the model clear to unfamiliar readers, we offer a brief sketch. ${ }^{6}$

\footnotetext{
${ }^{5}$ See Aimone et. al. (2013) for a comprehensive review.

${ }^{6}$ A full derivation of this model can be found in (D. M. Hungerman, 2014), we only offer a brief summary to motivate our empirical analysis.
} 


\section{Club Model of Social Enterprise}

In this simple version of the model, members maximize their utility over a private good $y$, a club good $x$, and the quality of that club good Q.

$$
U_{i}=U_{i}\left(y_{i}, x_{i}, Q\right)
$$

Subject to a resource constraint:

$$
\pi_{y} y_{i}+\pi_{x} x_{i} \leq I_{i}
$$

Where $\mathrm{I}$ is a resource endowment, and $\pi_{i}$ is the relative price. $\mathrm{x}$ is the local public good (which we will now refer to a "club good"), y is a private good. The club nature of $\mathrm{x}$ is expressed through $\mathrm{Q}$, which is a measure of "quality" for the club good. Quality is used as a general term, which captures the idea that the intensity and nature of other members participation is important to individual utility.

Specifically:

$$
\begin{gathered}
Q=f(\bar{X}, N) \\
\text { where } \bar{X}=\sum_{k \neq i}^{K} \frac{X^{k}}{N}
\end{gathered}
$$

So the average level of club good provision matters to individual utility, along with the total number of participants N. Utility increases with new members $(\mathrm{N})$, but only if they are of above average "quality".

Hungerman (2014) sketches a Nash equilibrium for the model, where higher prices for the private good increase utility, if the elasticity between the club good and private consumption is sufficiently high. The intuition of the here is that club members benefit both from their own consumption of the club good, but also benefit from the intensity and participation of other members. A corollary to the model is that relatively passive members (below average intensity) will reduce the utility of all other members. 
The higher price $\left(\pi_{y}\right)$ for private consumption creates an incentive for club participation by altering the relative prices. This increases aggregate welfare because of the positive externality to club good production. Similarly, high participation costs can create a separating equilibrium, where only those who value will contribute sufficiently to the club good $\mathrm{X}$ will join. Those who would be more likely to free ride will find it optimal not to join the club, because they do not value the club good sufficiently to bear the additional costs. The model is tailored to religious clubs, where $\left(\pi_{y}\right)$ may be prohibitions on secular activities such as alcohol consumption, gambling, or certain sexual activities.

The main idea of the model is that religious consumption will be more valuable once less fervent adherents are "screened out". Consequently, it becomes much more viable to produce the club (religious) good. The theoretical model has been supported by experimental evidence. Voluntary contributions to club goods were much higher and sustainable once groups were able to select out free riders (Aimone, Iannaccone, Makowsky, \& Rubin, 2013).

Social entrepreneurs have struggled to develop business models that overcome free riding. One useful example is the news industry, a social enterprise by our definition. Since the popularization of online content publishing, news organizations have experimented widely with their pricing models. At one extreme is the Wall Street Journal which erected a hard paywall to limit users who haven't contributed, thus privatizing their output, though significantly limiting their reach and influence. At the other extreme is National Public Radio, which has used the model of soliciting donations, while distributing their content widely. Other news agencies have found middle ground, with an intermediate mix of paywall and donation revenues.

This range represents the strategy space for social enterprises. How then should ventures choose the appropriate mix of revenue streams, set their prices, and weigh the trade-off between revenue and reach? The club model helps to clarify this question. To the extent 
that the quality of the local public good produced by the social enterprise relies on the intensity of participation by its constituents, then the club model indicates that managers should consider raising the cost of participation. Managers of clubs may accept the lower levels of output in return for higher quality participation.

Alternatively, other social enterprises will want to see the reach of their output maximized. The average level of participation or engagement will not be primary objective. Anti-poverty or policy advocacy programs may better fit this mould. The experience value of participation by one constituent, is not (per se) contingent on the intensity of participation by others. In this cas,e the pure public goods model of private provision is appropriate. Output is maximized and some alternative revenues, most likely donative, will be deployed.

More commonly, social enterprises will produce a mix of goods, some with club good and others with pure public good characteristics. For example political advocacy organizations will require a core group of constituents for community organization and outreach. These individuals will make their own choice of effort contingent on the choices of their peers. Counter to intuition, identifying a sufficiently robust level of exclusion can improve the overall production of the club good. Thus a club model of selection is important. We next test specific hypotheses of the club model on a sample religious institution, then discuss potential implications for social enterprise more generally.

\section{Religious organizations as social enterprise}

This paper will examine the financing scheme used by an American religious institution to produce a public good. The object of our study begs the question; do institutions pursuing religiously motivated social objectives offer insights for social enterprises more generally? Some social entrepreneurs have been sceptical, arguing that religious institutions cannot be viewed as social enterprises. They have argued that religious firms pose a "threat" to the social enterprise "movement" 
(Esposito \& Pelsinger, 2014). Alternatively, other authors have noted parallels in language and strategy between environmental social enterprises and religious sects (Bose \& Komarek, 2015). Consistent with Santos'(2012) positive definition of social enterprise, we argue that there should be no restriction on the particular type of public good a social enterprise may produce, allowing us to analyze religion through a market framework. ${ }^{7}$

Furthermore, economic theory has made steady advances in applying standard industrial organization models to interpret, explain, and predict the behaviour of religious institutions. See Iyer (2016) and Hungerman (2010) for comprehensive reviews. Economists have also successfully applied market structure theories to explain the behaviour of religious institutions in historical contexts dating back centuries (Ekelund, Hébert, \& Tollison, 2006). In a relevant decision, the US Supreme Court has recently upheld the right of privately held companies to pursue religiously motivated objectives (US Supreme Court, 2013). Thus, for legal scholars, examining the behaviour of religiously motivated for-profit firms is now keenly relevant. Finally, religious belief has been offered as a significant motivator for social entrepreneurs (Roundy \& Taylor, 2016).

Most importantly, churches, their respective denominations, and hierarchies appear to match the definitions of social enterprise put forward in the existing literature. In a comprehensive review, Dacin \& Dacin (2011) attempt to distil a common theme from various definitions of social entrepreneurship across thirty-seven recent papers.

Dacin \& Dacin (2011) conclude:

We believe the definition that holds the most potential for building a unique understanding of social entrepreneurship and developing actionable implications is one that focuses on the social value

${ }^{7}$ In an extensive treatment of religious competition during the first two centuries of United States history, Fine and Stark (2005) describe how Baptist and Methodist applied recognizable economic strategies to overtake incumbent Presbyterian and Congregational churches 
creation mission, both positive and negative, of undertakings aimed at creating social value. (p.42)

Social value in this definition is consistent with our public good definition of social entrepreneurship (Santos, 2012, p.337). We claim that existing definitions of social entrepreneurship offer no guidance regarding which social values entrepreneurs may pursue, or how one might define positive. Social value is inherently subjective, variable over time and across individuals. Thus, religious institutions which promote a distinct type of social good can offer valuable insights for the field of social entrepreneurship in several important ways.

\section{Advantages of using religious institutions to study social enterprise}

Religious institutions offer social entrepreneurship researchers unique opportunities for research. First, religious institutions provide a rich set of empirical data. Many religious institutions are meticulous recorders of revenues, expenses, and output. These records are typically available to the public, and provide a detailed look at religious production. In contrast, current social enterprise firm-level data is often unrecorded or proprietary. To illustrate, Hand (2016) meticulously identifies the current twenty-five most influential academic articles in social entrepreneurship. More than half of the sample deals with definitions of social entrepreneurship. The others explore theory and research frontiers of the field. None offer a substantive empirical analysis of any social enterprise. The lack of empirical studies in the literature is a likely contributor to the slow progress in establishing academic credibility in social enterprise.

Second, religious firms offer records over extraordinarily long periods of time. Obvious examples include the Roman Catholic or Orthodox churches, which maintain stable institutions and record keeping that date back millennia. More recent protestant denominations have formal institutional structures and record keeping 
that can date back dozens, or hundreds of years. Their longevity stands in sharp contrast to typical social enterprise research.

Long data frames are particularly important for social entrepreneurship research. For classical for-profit firms, researchers can apply theories of profit maximization, which are safely assumed to remain stable over time. This is not necessarily true for social enterprises. How any particular social cause is "valued" may vary dramatically over time. Consider any array of contemporary organizations that deal with political, environmental, or social causes. How would their activities be valued now, versus fifty or one hundred years in the past? A modern environmental cause might seem as absurd in 1920 as a temperance league would appear today. Very long-lived institutions are one avenue to extend analysis out from our own social context, and to examine how social enterprise adapts to changes culture, demographics, and political regimes.

Finally, and most significantly, religious institutions face the same core problem as social enterprises; they must finance collective output while mitigating free-riding among its constituents. Religious instructions have been extremely adaptive in the tools they employ to overcome this challenge. Iannaccone and Bose (2012) describe the various models of financing discussed previously. Stark (1996, 2015)describe the intense competitive forces that, particularly U.S., religious sects endure to finance and promote their objectives.

For these reasons, we propose that religious institutions can be viewed as a specific type of social enterprise, and subject to economic analysis. They offer particular advantages to advance our knowledge of social entrepreneurship by offering reliable, open, long-term data. Using this information, we can examine how religious institutions have evolved to overcome the difficulties in financing collective goods. To make our analysis tractable, we focus our attention on one particular religious institution in the United States, the Southern Baptist Convention. 


\section{Overview of the Southern Baptist Convention}

This paper will use historical financial data from the Southern Baptist Convention (SBC) for its analysis. The SBC is the largest protestant denomination in the United States, claiming more than sixteen million adherents in 2010 (Lindner, 2012).

\section{Southern Baptist Convention History \& Governance}

The SBC traces its roots to the Reformation era in England. Reformers maintained an emphasis on adult baptism, and fled persecution in England for the United States in the early seventeenth century. Expansion of Baptist churches continued rapidly through the mid nineteenth century, by emphasizing the use of lay pastors and outdoor preaching (Finke \& Stark, 2005). In 1845, the Southern Baptist split from Northern Baptist over the issue of allowing slave owners as missionaries (Baker, 1974).

SBC governance is highly decentralized. Each of its approximately 40,000 churches operate as independent, self-governing entities. The local church is an autonomous unit of the SBC, with the authority select its own pastor and leadership. However, it is common for SBC churches to affiliate with a state convention, of which there are currently 42 in the United States. The state conventions then coordinate with the national convention, which meets annually to conduct business.

The convention is overseen by an executive committee. This committee oversees the budgets for four standing "boards" or institutions that receive funds from the national convention. These boards include: Guidestone Financial Resources - which oversees SBC pensions, LifeWay Christian Resources - which handles publication and research, the International Mission Board (IMB) - which supports international missions, and the North American Mission Board (NAMB) - which supports missionary personal domestically. The executive committee also oversees budget allocation to eight SBC seminaries. 
Our interest lies in the activities of this national convention. The $\mathrm{SBC}$, like most religious institutions, produces a variety of religious services, social welfare, education, recreation etc. Different goods and services produced by the SBC have varying degrees of public good characteristics. Our analysis will focus its attention on missionary financing and production by the SBC. Foremost, missionary production fits well with our definition of a local club good. For SBC members, the value of missionaries is non-rival and non-excludable. Yet these missionaries would have zero (or possibly negative) value for individuals outside of the SBC. There is also the practical reason where, unlike other types of production, the SBC has kept consistent records of foreign missionary production for nearly a century. It is reasonable to consider missionary production as a proxy for overall religious production by the $\mathrm{SBC}$.

Both the IMB and NAMB directly sponsor and support full-time vocational missionaries. Producing and sponsoring new missionaries is valuable to most SBC members. The SBC ascribes the need for missionaries to New Testament Scripture, which commands: "But you will receive power when the Holy Spirit has come on you, and you will be My witnesses in Jerusalem, in all Judea and Samaria, and to the ends of the earth" (Act 1:8, The Holman Christian Standard Bible). SBC statements of basic beliefs support this scriptural claim, "It is the duty and privilege of every follow of Christ and every church of the Lord Jesus Christ to endeavour to make disciples of all nations...". The IMB and the NAMB are the primary institutional vehicles for missionary production and support in the SBC.

The consumption of missionary activity is central to SBC members. There may be "eschatological consumption", where an adherent believes that the spreading of the Gospel through missionaries brings about fulfilment of a scriptural historical narrative. Alternatively, the adherent may simply consume the extra status and ancillary benefits from being part of a larger group, via expansion of new believers.

\footnotetext{
${ }^{8}$ http://www.sbc.net/aboutus/basicbeliefs.asp
} 
Neither of these types of consumption are excludable to SBC members. The SBC cannot prevent, in a literal sense, the consumption value provided by additional missionary activity, even if the adherent did not contribute financially to their support their costs.

Missionaries are also non-rival. Once a missionary has been put in place, one adherent's consumption of their work does not prevent another's. These two conditions would likely lead to an equilibrium of under provision described previously. Again, this is a core problem faced by every social entrepreneur. However, the SBC has evolved an informative set of tools designed to mitigate the free rider problem.

\section{SBC Collective Financing Schemes}

The SBC has two primary mechanisms for financing missionary production. The larger of the two programs is the Lottie Moon (LM) Christmas offering. The annual offering began in 1888, and was named for the influential female missionary in $1918 .{ }^{9} \mathrm{LM}$ is interesting because it is most similar to typical fundraising programs of many charitable organizations. Individual families choose how much to give in private, where donations are largely anonymous to other church members. Furthermore, their private donation is competing against the large number of other ways they could have allocated those gifts. For every dollar a family chooses to give to LM, their personal consumption is reduced by one dollar. The LM is our base case for voluntary contributions to the club good.

The second vehicle for missionary financing is the Cooperative Program (CP). The CP was started in 1925 as a collective mechanism for supporting international missions. In the case of the $\mathrm{CP}$, the church is the giving agent. Both of the decisions (whether to give and how much to give) are made at the church level, out of undesignated revenues. Contributions decisions to the $\mathrm{CP}$ are made by an elected church board, who face different incentives than an individual family. Foremost, contributions decisions are public to the entire group.

${ }^{9}$ Lottie Moon was a female missionary to China from 1873 to 1912. See https://www.imb.org/lottie-moon-christmas-offering for more information. 
Budget decisions are typically discussed openly in church meetings. Further, when a board member votes to increase the contributions of their church by one dollar, the value of the collective good increases by one dollar, but the impact on any one family's current consumption is negligible. In this sense, the $\mathrm{CP}$ operates similarly to corporate charitable giving, where agency issues are more acute. Later in our analysis, we will be interested if there are systematic differences in these two giving vehicles.

Figure 1 depicts real (2009 dollar) contributions to the CP and LM programs since 1935. The SBC has created a remarkable financing system, spanning decades. From the start of our time frame (1935) until 1985, real (inflation adjusted) contributions to LM increased, on average, by $11 \%$ year. Contributions to the $\mathrm{CP}$ increased, on average by $8 \%$ annually. However, there is a noticeable change in donation patterns after 1985, this is particularly true for the CP. Post 1985, donations grew, on average, by $1 \%$ annually for LM and there was no net change in real contributions to the Cooperative Program for the past thirty years.

Our ongoing questions for this paper. What factors attributed to the successful fundraising by the SBC for much of the twentieth century? What factors lead to the relative collapse of fundraising by the SBC after 1985? Finally, why has the LM fundraising strategy proven more robust in recent decades relative to the $\mathrm{CP}$ ?

\section{Data}

The SBC meets annually to conduct its national business. Each national convention produces a written record of its activities, called the SBC Annual. Our interest in the SBC coincides with the emergence of the Cooperative Program for funding international missionaries, which was initiated in 1925. 
The data begins in 1935, once record keeping and the CP program stabilized. The SBC annuals are archived as scanned PDFs. ${ }^{10} \mathrm{We}$ extracted the relevant tables from the annuals in five year increments (i.e. 1935, 1940, 1945 ... 2015), giving us seventeen periods. Though the SBC annuals are available for each year, the data required extensive by-hand data entry, so we chose to only record every fifth year. Records are organized by state convention, thus state-year contributions will be our unit of observation.

Because of the growth of the SBC, only a few southern states (i.e. Alabama, Georgia, etc.) appear in the earliest panels, while northern and western states (i.e. Iowa, Nevada, etc.) begin appear in later panels as Southern Baptist churches spread outward in the twentieth century. Southern Baptist churches are typically organized into individual state conventions; however, a few states were grouped into multi-state regions (i.e. New England, Oregon/Washington, etc.) where church populations are more diffuse. Of the thirty-eight state/groups available, 19 were observed over every period. The remaining were added to SBC annuals in later periods. In all, there are 513 state/year observations available for our analysis.

\section{Contributions to the club good}

Our primary variables of interest are state level contributions to international missions via the Cooperative Program (CP) and Lottie Moon (LM) offerings. Table 1 gives the inflation-adjusted values for both the CP a LM in constant 2009 dollars. The strongest growth for both CP and LM came in the early half of the twentieth century, boasting double-digit real gains for several decades. However, since late mid-century, contributions to both CP and LM have stagnated. The CP peaked (in real terms) around 1990. LM managed modest additional gains, until turn of the millennium, peaking in 2005. After,

\footnotetext{
${ }^{10} \mathrm{http}: / /$ www.sbhla.org/sbc annuals/index.asp
} 
2005, funding has collapsed. In particular, CP contributions have fallen in real terms to levels observed in the 1980's.

The data structure provides us two forms of variation: across US state conventions, and within those conventions over time. Table 2 presents the total nominal dollar amounts given to the CP by each state and year. Because of wide variation in state population, it is not surprising that large states, like Texas, Georgia, and Florida, maintain the largest levels of contributions. Alabama is a notable outlier. Alabama has roughly one-fifth the population of Florida, yet exceeds it in contributions. The largest and longest-lived contributors are located in the south-eastern part of the US, consistent with the history of the Southern Baptists. Sates outside of the southeast region were added gradually throughout the twentieth century, creeping north and westward. ${ }^{11}$ Nominal LM state contributions (Table 3) follow a similar pattern, though they follow state populations more closely.

\section{State Data}

Because we are interested in explaining the contributions by states to either the $\mathrm{CP}$ or LM over time, we also collect basic state demographic data over our relevant time horizon (1935 - 2015). Table 4 presents our demographic data by state. The variables include the number of Southern Baptist Churches (as reported in SBC Annuals), government transfer payments (i.e. social security, public assistance, and unemployment), per-capita income, state population, and race (percent black). Table 5 presents these averages by year, instead of state.

\section{Religious Exclusion Cost}

We are interested in testing the impact of exclusion mechanisms in order to promote contributions to the club good. The SBC has

${ }^{11}$ A notable outlier in the data is Oregon/Washington, which expresses positive values beginning in 1950, then stops in 1985. This is a result of SBC state level conventions where, after 1985 Oregon/Washing was subsumed into a larger Northwest convention. Because the geographic boundaries are imprecise, regional conventions (i.e. Northwest or New England) were dropped from the sample. 
remained remarkably consistent in its religions doctrinal provisions. ${ }^{12}$ Thus, we do not have a significant variation in the exclusion costs imposed on its adherents. Alternatively, we will look for variation by examining changes in the opportunity cost of adherence, by documenting the availability of competing sects. We do this by measuring the availability of alternative religious denominations, while holding constant the strictness of SBC.

Unfortunately, comprehensive religious affiliation data is not available by state, particularly over our long time frame. Instead, we divide state population into the number of SBC churches to generate a SBC church density metric. We use this as a proxy for religious exclusion, whereby a higher concentration of SBC churches per state lowers the cost of adherents. Conversely, lower concentration of SBC churches implies lower cultural dominance. It is more likely that existing or potential adherents have lower cost alternatives to SBC membership.

\section{Secular Exclusion Cost}

Hungerman (2010) argues that, when examining markets for religious services, researchers should analyse both intra religious competition and competition against secular alternatives. He outlines an effective method for doing so in a series of papers that examine the repeal of "Blue Laws" by states over the previous century (Gerber, Gruber, \& Hungerman, 2016; Gruber \& Hungerman, 2008; D. M. Hungerman, 2014). Blue laws are religiously motivated laws (such as prohibition against alcohol or Sunday retail sales) which were named for their printing on blue paper. Blue laws have gradually been repealed by US states over the last century. Hungerman demonstrates that the blue law repeals both signal a change in culture and alter the relative opportunity cost of participation in religious activities.

Our Table 6 is adapted from Gruber \& Hungerman (2008), which gives the year that each state voted to repeal it's blue laws. Gruber

${ }^{12}$ A complete catalog of SBC resolutions can be found at http://www.sbc.net/resolutions/. 
and Hungerman note that many states are not included in the table because; either they never had blue laws, or the blue laws were repealed at the county level. We will seek to expand the detail of this blue laws list as this paper develops further. By including a set of indicator variables for when secular competition increases, we hope to identify points of cultural change that indicate an increase secular competition for religious services.

\section{Empirical Model and Hypotheses}

Our aim of this paper is to test the club model of public goods financing on mitigating free riding. We examine the test case of the Southern Baptist Convention. As discussed previously, we are looking at two distinct financing schemes over time and across US states. The baseline models are as follows:

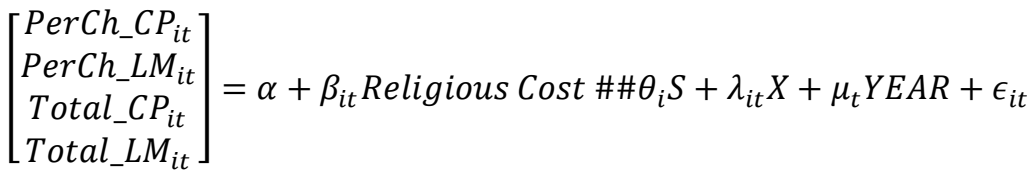

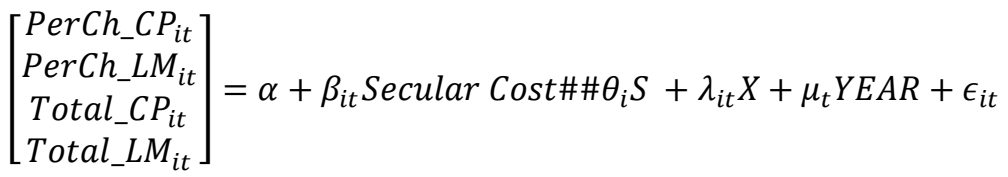

The models will test four dependent variables: per-church giving to the Cooperative Program (PerCH CP), total giving to the CP (Total $\mathrm{CP}$ ), per-church giving the Lottie Moon (PerCH LM), and total giving to LM (Total LM) for state $i$ and year $t$.

We examine exclusion costs in two ways. First, a significant cost of adherence is the forgone opportunity to participate in a competing religious sect. Religious Cost is lowest in an environment that is dominated by a single religious provider. The opportunity cost will rise as the religious environment becomes more pluralistic and competitive. We constructed this proxy as the number of Southern Baptist churches in the state, divided by the state population where 
those churches are located. ${ }^{13}$ This implies that greater religious concentration (moving toward monopoly) will result in a lower cost. Conversely, greater religious plurality implies a high opportunity costs for participation in any one sect.

We calculate a measure of density for SBC churches by state, specifically the number of churches per 10,000 persons of state population Church Density $=\left(\frac{S B C \text { Churches }}{S T A T E \text { Population }}\right)$. Table 7 lists the mean number of churches per 10,000 in population, by state. Not surprisingly, "deep south" states such as Alabama, Mississippi, and Georgia have the highest concentration of SBC churches. Northeastern and northwester states, where the SBC spread much later, have lower concentrations of churches. To be consistent with the notion of lower church density implying higher costs, we construct Religious Cost $=\left(\frac{1}{\text { Church Density }}\right)$. Thus, higher values of Church Density implies lower membership costs.

Second, contributions of time and money to religious activities represent forgone secular consumption. To capture this, we adopt a set of dummy variables that tracks the repeal of Blue Laws in a particular state. Blue laws repeal imply a higher cost of religious participation, because greater secular opportunities then become available. Thus, Secular Cost $=1$ indicates that a Blue Law was repealed in year $t$ and state $i$.

Finally, $\mathrm{X}$ is a vector of state level covariates including: (PerCapita Income; Government Transfers; and race (measured as percent black)). We include a full set of state and year dummy variables. Table 8 presents summary statistics for all covariates.

\section{Hypotheses}

There are opposing views as to whether contributions to the club good will increase or decrease with higher exclusion mechanisms. On one hand, high levels of church density imply amplified cultural

\footnotetext{
${ }^{13}$ Unfortunately, we were unable to attain reliable church membership (Southern Baptist or otherwise) estimates at the state level over this time span.
} 
dominance, social conformity, and returns to religious signalling. These forces will encourage additional contributions, because the marginal benefit to conformity is high. Furthermore, increasing church density will simply make it more likely that potential adherents are solicited more often for contributions (Bekkers \& Wiepking, 2011). Experimental research has demonstrated that voluntary contributions are positively influenced by social conformity and positive self-image (Gneezy, Gneezy, Riener, \& Nelson, 2012). This story would indicate that contributions (CP and LM) will be inversely correlated with Religious Cost.

On the other hand, religious market power implies that it is easier for an individual to free ride by escaping detection. Non-contributors find it easier to pose as an adherent, because of its dominance of the ambient culture. Further, cultural dominance could reduce product innovation on the supply side, thereby discouraging adherence. This story would imply a positive relationship between Religious Cost and per-church contributions. Empirically, Zalezki and Zech find that congregations in low density (high competition) markets actually give more. They argue competitive churches are more sensitive to consumer needs, and find niches in the religious marketplace (1992).

\section{Hypothesis 1 \& 2: Per-church contributions will increase with Religious Cost.}

Iannacone and Bose (Iannaccone \& Bose, 2012) offer a way to separate these competing narratives. Their paper distinguishes between collective and private religions. Collective religions operate like clubs, where adherents are viewed as members, rather than patrons. Collective religions are usually theologically exclusive, and often impose costly lifestyle and moral codes to identify true members (Iannaccone, 1992). Collective (or club) religions include Christian Evangelical traditions (including the Southern Baptists), along with Mormonism, and stricter forms of Islam. Group participation, identity, and distinctions between in-group and out-group matter a great deal 
in these faith traditions. Somewhat counterintuitively, hegemony of these types of religions will likely reduce individual contributions to the collective good. As these religions become larger, the ability to enforce conformity and monitor free riding declines. Second, any individual's marginal contribution to the club good will be small, particularly as the total size of religious club goods increases. Thus, for collective religions, we expect that per church contributions will move positively with Religious Cost (Zaleski \& Zech, 1995). ${ }^{14}$

Southern Baptist convention falls well within what Iannaccone and Bose (2012) characterize as a collective religion. Though enforcement has varied, historical Southern Baptist teaching has historically included significant lifestyle prohibitions including: abstinence from alcohol, gambling (including most card play), and sexual activity outside of traditional marriage. ${ }^{15}$ In the affirmative, Southern Baptist tradition calls for a public profession of faith by immersion baptism. These characteristics impose a high cost on those with relatively low religious adherence, making the SBC a club style religion. Consistent with theory of club religions, we expect that giving to the collective good by adherents within the SBC will move positively to Religious Cost (inversely to church density). Formally:

$$
H 1: \frac{\delta(P e r C h C P)}{\delta \text { Religious Cost }}>0 \quad H 2: \frac{\delta(\operatorname{PerCh} L M)}{\delta \text { Religious Cost }}>0
$$

We report our empirical results for $\mathrm{H} 1$ and $\mathrm{H} 2$ in Tables 9 and 10.

14 For contrast, Iannaccone \& Bose (2012) describe private religions as those that act more like secular commercial firms. Examples of private religions include Chinese "folk" traditions, Greco-Roman paganism, and American "New Age/Spiritualism”. For private religions, brand loyalty is rare, and theology is less exclusive. Religious services are typically provided as fee for service. Patrons often construct a religious portfolio of goods and services, encompassing many different traditions that meet an adherent's particular tastes. In particular, private religious are those for which participation, allegiance to that particular group matters less. Religious patrons are free to shop around for religious services from different vendors without stigma. Thus, private religions are more likely to be adversely influenced by religiously competitive environments.

15 See http://www.sbc.net/resolutions, and search by keyword for various resolutions. 


\section{Hypothesis 3 \& 4: Per Church contributions to CP or LM will increase with Secular Cost.}

As discussed previously, Hungerman presents evidence that secular competition is just as important in religious markets (Gerber et al., 2016; D. Hungerman, 2010; D. M. Hungerman, 2014). Intuitively, religions traditions compete for time and resource both among existing religious traditions and against secular competitors. We adopt Hungerman's use of Blue Laws by state as an instrument for Secular Cost.

Under the club religions model, competition between secular and religious activities plays out similarly to intra-religious completion. In club religious, the free rider problems dominates, thus imposing higher cost has the effect of increasing per-church contributions. Thus, we expect that:

$$
H 3: \frac{\delta(\operatorname{PerCh} C P)}{\delta \text { Secular Cost }}>0 \quad H 4: \frac{\delta(\operatorname{PerCh} L M)}{\delta \text { Secular Cost }}>0
$$

We report results for $\mathrm{H} 3$ and $\mathrm{H} 4$ in tables $11 \& 12$.

\section{Hypothesis 5 \& 6: Total contributions to CP or LM will decrease with Religious Cost.}

Under the club model, increasing the exclusion mechanism should increase per-church contributions, but the effect on total contributions is ambiguous. If price elasticity is sufficiently high, increasing the exclusion mechanism will reduce total contributions to the club good because a large number of potential members are excluded. While not making a strong prediction, we test this outcome by looking at whether increases in Religious Cost subsequently reduce total state contributions to LM and CP. ${ }^{16}$ Specifically:

16 To normalize the distribution, we take the natural logarithm of total contributions. 


$$
\text { H5: } \frac{\delta(\text { lnTotal_CP })}{\delta \text { Religious Cost }}<0 \quad H 6: \frac{\delta(\text { lnTotal_CP })}{\delta \text { Religious } C o s t}<0
$$

\section{Hypothesis 7 \& 8: contributions to CP or LM will increase with Secular Cost.}

We perform a similar test for Secular Cost. Specifically, we test:

$$
\text { H7: } \frac{\delta(\text { lnTotal_CP })}{\delta \text { Secular Cost }}<0 \quad \text { H8: } \frac{\delta(\text { lnTotal_LM })}{\delta \text { Secular } \operatorname{Cost}}<0
$$

\section{Hypothesis 9 \& 10: CP will express lower sensitivity to variation in religious and secular competition, relative to the LM program.}

Recall there are two distinct channels provided by the SBC for missions funding. The LM Christmas offering is representative of traditional forms of philanthropy. Gift amounts are largely anonymous, and the donor bears the full cost of the donation. The decision to contribute to the $\mathrm{CP}$ program are made differently. Contributions decisions are public, and made by a committee (often of church deacons). Since contributions from to the $\mathrm{CP}$ program are from unrestricted church budgets, the cost of the initial donation is already sunk. Experimental evidence demonstrates that exclusion mechanisms should be most effective when contributions are anonymous (Aimone et al., 2013). Thus, we expect that the impact of religious and secular cost will be larger for LM than CP. Formally,

$$
\begin{gathered}
\text { H5: }\left|\frac{\delta L M}{\delta \text { Religious Cost }}\right|>\left|\frac{\delta C P}{\delta \text { Religious Cost }}\right| \\
\mathrm{H} 6:\left|\frac{\delta L M}{\delta \text { Secular Cost }}\right|>\left|\frac{\delta C P}{\delta \text { Secular Cost }}\right|
\end{gathered}
$$

The practical implication of this hypothesis is that $\mathrm{CP}$ should be a more stable source of financing, relative to LM contributions. 


\section{Results}

\section{Results related to Hypothesis 1 \& 2:}

Table 9 presents results from the regression on Per-Church LM contributions. Our primary interest is in the impact of Religious Cost on per-church LM contributions. The model includes interaction effects, which are suppressed for presentation purposes in the regression tables. To ease interpretation, we include the marginal effect for Religious Cost below the full regression table. The point estimate should be interpreted as the effect of an increase in 10,000 state residents, for a given number of churches in the state. When the density of churches in a state is reduced (thereby increasing the opportunity cost to the adherent) average per-church donations to the Lottie Moon missions offering increase by $\$ 101.74$. This effect is large, statistically significant, and consistent with $\mathrm{H} 1$.

Table 10 presents the results for the regression model on the Cooperative Program (CP). Recall that the $\mathrm{CP}$ is the fraction of church revenues that are allocated to foreign missions. Again, the point estimate is interpreted as the effect of increasing the state population by 10,000 on the average contribution of a church in that state. The marginal effect of Religious Cost indicates that increasing the population by 10,000, holding churches constant, will increase perchurch contributions by $\$ 59.24$. Again, the effect is large, statistically significant, and consistent with $\mathrm{H} 2$.

\section{Results related to Hypothesis $3 \& 4$ :}

We next looked at the effect of secular competition on contributions to the club good. Our primary variable of interest is now Secular Cost, a dummy variable indicating the year a particular state repealed their Blue Laws. Thus, secular costs increase when Secular Cost $=1$. Recall that not every state experienced a state-level change in blue laws during the sample frame. Only states in Table 6 are included in the regression sample. This regression also removes state and year dummy variables to prevent collinearity. 
We interact Secular Cost with State so that we can isolate the individual of the blue laws for each state affected. Table 11 reports both the marginal effects for Secular Cost and Secular Cost by State for the regression on per-church $\mathrm{CP}$. The table shows that the average treatment effect, for all states and years, was to increase per-church contributions to the $\mathrm{CP}$ by $\$ 1,271.55$. The effect is large, and statistically significant. Repealing Blue Laws in the states where the sample is available increases, on average, real contributions to the $\mathrm{CP}$ by sixty percent. The bottom section of Table 11 shows the marginal effects for each state that contained enough data to form an estimate. We observe a statistically significant impact of repeal in half of those states that were tested (Kansas/Nebraska, Ohio, Tennessee, and Texas). The remainder were indistinguishable from zero. ${ }^{17}$

Findings were similar for contributions to the LM Christmas offering, shown in Table 12. Again, for clarity, we only display the marginal effect for Secular Cost and then for Secular Cost interacted with each State. Similar to the results for CP, per church contributions to LM increase with Secular Cost. The magnitude of the effect is very similar, increasing average contributions by $\$ 746.74$, though the effect was only significant at larger confidence intervals $(\alpha=.10)$. Again, the same states demonstrated statistically significant increases in contributions subsequently to the Blue Laws repeal. These results broadly support $\mathrm{H} 3$ and $\mathrm{H} 4$.

It is worth noting again that many states in the sample could not be tested. Alabama, for instance, repealed blue laws at the county level, thus a state observation is not possible. Efforts to integrate these, and other, states back into the sample are ongoing.

\section{Results related to Hypothesis 5 \& 6}

From the club model, we expect that per-church contributions will increase with stronger exclusion mechanisms. However, the impact on total contributions is ambiguous. The total impact on contributions

${ }^{17}$ It is important to remember that $\mathrm{CP}$ has been deflated to real values, so this effect is not impacted by general inflation. 
depends on the sensitivity of adherents to the exclusion mechanism on the extensive margin. It is plausible that increases in the exclusion mechanisms may increase per church contributions, while decreasing overall contributions. We test this by regressing exclusion (religious and secular) costs against total contributions to LM and CP.

Because the coefficient is difficult to interpret, Table 13 reports the elasticity of the marginal effect below the main regression. The impact of an increase in Religious Cost (lowering church density) on total contributions by ten percent, reduces total contributions to LM by one-half of one percent. The effect size is modest, but statistically significant. Increasing the religions exclusion lowers aggregate contributions, but not by much. We find a similar result for the impact of Religious Cost on the contributions to CP, reported in Table 14. In this case an increase in Religious Cost of ten percent reduces total contributions to the CP by eight tenths of one percent. Again, modest, but statistically significant. These results support H5 \& H6.

We then examine the impact of increasing Secular Cost. For brevity, we only post the marginal effects of the exclusion costs (Religious Cost and Secular Cost) in Table 15. The regression model does not show a statistically significant effect. The most plausible interpretation of these results is that increases in per-church giving (intensive margin) are offset by declining total giving. While not specifically supporting $\mathrm{H} 7 \& \mathrm{H} 8$, these results are consistent with the club model.

\section{Results related to $\mathrm{Hg} \& \mathrm{H1O}$}

In our final set of results, we examine the differences in impact between contributions to CP and LM. Recall that we are interested if the two types of financing schemes produce different levels of contribution to the club good when religious and Secular Cost vary. LM offerings are individual, anonymous, and repeatable. Thus they mimic individual giving patterns for many types of public goods games. 
In contrast, $\mathrm{CP}$ contributions are public, and set by committee at the church level. We have shown that contributions to both LM and CP increase with when the cost of participation rises. This is the theoretical prediction for collective religions. However, we also have the opportunity to observe differences in fundraising effectiveness across two distinct fundraising schemes for the same public good.

Table 16 offers a simple t-test between the marginal effects of Religious Cost on $\mathrm{CP}$ and LM contributions. The test confirms a statistically significant difference between the two financing mechanisms. However, we do not get the expected sign. Contributions to the $\mathrm{CP}$ were more responsive to changes in Religious Cost compared to contributions to LM. . This finding is not supportive of H5. Contributions to $\mathrm{CP}$ appear to be more sensitive to changes in the religious competitive environment than do contributions to the LM. This finding is not consistent with our club theory model, and worthy of further inquiry.

Table 17 reports a t-test between the marginal impacts of Secular Cost on CP and LM contributions. In this case, we cannot detect a statistically significant difference between the two effect sizes. The point estimates are consistent with our previous test. The impact of Secular Cost is more pronounced for contributions to CP, compared to LM. Again this is unexpected, considering the decision making process of a church committee should be, ex-ante, less reactive than individual donors.

\section{Conclusions \& Lessons for Social Enterprise}

This paper began with the premise that social enterprises can be identified by their production of public goods. Given this definition, all social entrepreneurs face a common struggle; to finance production when free-riding is optimal by their constituents. A common tactic is for governments to employ their unique ability to tax, which mitigates free riding. However, for those social enterprises which are not 
supported by government budgets, or wish to supplement those funds through voluntary financing, other strategies must be developed.

Social entrepreneurs may attempt to charge a premium mark-up linked to their public good. Strategies for this include tying their public good to a private product, or by erecting a paywall to charge a price in excess of marginal cost (as with the WSJ). Of course, by doing this, the social enterprise limits the scope and influence of their public good.

Alternatively, the social enterprise may choose to lower their price - perhaps to zero- to maximize the reach of their product. Examples include political advocacy organizations and most aid NGOs. However, this choice requires generating alternative revenues, typically through voluntary donations (as with NPR). Though social enterprises have engaged a range of these approaches, there is little theoretical (or empirical) guidance as to when, or under what circumstances, to pursue either strategy.

This paper takes an evolutionary approach, by examining institutions that have proven durable at providing public goods over very long time horizons. Religious institutions have deployed a remarkable variety of schemes to facilitate production of religious public goods. Analyzing these institutions may offer valuable lessons for social enterprise today. We have focused on one large religious institution, the Southern Baptist Convention which produces a costly public good, international missionaries. Over the past century, the SBC has produced and deployed one of the largest professional missionary forces in the world, employing millions of dollars and thousands of workers over the past eight decades. SBC missions programs reached their funding zenith around the turn of the millennium. However, recent financial stress has caused the International Mission Board to reduce their staff by nearly one thousand full time missionaries, and liquidate many of foreign assets (Smietana, 2015).

Iannaconne and Bose (Iannaccone \& Bose, 2012) describe Southern Baptist as a collective religion. Collective religions rely heavily on strong group identity and high-cost religious activities to effectively exclude insufficiently fervent adherents. Relative to private religions, 
collective religious have strong club goods characteristics that are amenable to the sustainable production public goods.

Counterintuitively, the club theory of religions predicts that adherents of collective religions can increase their output of the club good when the cost of membership is higher (Aimone et al., 2013; Eli Berman \& Laitin, 2008; Iannaccone, 1992). We tested this conjecture by examining SBC giving data to international missions from 1935 to present day. Our analysis examined both intra-religious competition and secular competition. Consistent with the club theory of religion, we find that per-church contributions to missions are higher when religious competition increases. Furthermore, secular competition was also correlated with higher contributions to the public good. These findings do not, however, help explain the relatively recent collapse in missions funding in the SBC, which is an area of ongoing inquiry.

Our analysis further sought to exploit a peculiar aspect of SBC governance where contributions to missions is collected by two distinct means. The annual Lottie Moon Christmas offering is most similar to typical voluntary charitable donations. LM contributions are anonymous and the household bears the full cost of the donation. This mechanisms is different than contributions through the Cooperative Program. Giving through the CP is aggregated at the congregation level. Giving is authorised through a committee of elders from unrestricted church funds. The dollar value of the contributions is published publicly, while the cost of the gift is dispersed through the congregation. Counter to our expectations, we did not find any meaningful difference between these two contribution schemes.

Though this paper has focused on religious institutions, we believe that there are lessons to be applied to social enterprise in general. The club model of religion offers an illuminating method for mitigating these problems.

Under specific circumstances, making membership in your club costly (exclusive) may increase the average willingness to voluntarily contribute. There are various strategies, from demanding sacrifices (in terms of time and money), to outrageous signals of allegiance 
(countercultural dress codes or behaviours). These signals may create a separating equilibrium, which both mitigates defection by true followers, and screens less enthusiastic adherents (Iannaccone, 1992). These practices run counter to the logic of competitive markets, where lowering the costs and barriers to consumers is the dominant competitive strategy.

This paper demonstrates that the strategies employed by a collective religion operating within club model of membership has been successful producing a club good over a long time period. Other examples in the literature include ultra-orthodox Jews (Eli Berman, 2000) and Hamas (Eli Berman \& Laitin, 2008) and environmental organizations (Bose \& Komarek, 2015). Each demand high levels of commitment and public sacrifice. In return, clubs mitigate free riding and create an environment conducive to the production of public goods. Importantly, Beman \& Laitin (2008) argue that it is the structure and practices of the organization, not the religious claims or mission of the organization that are key to member allegiance.

Individual incentives to free ride, combined with competitive pressures, whittle away a firm's ability to divert resources to finance the club good. Can a social enterprise follow a strategy similar to private religious clubs? Could the club model of religion offer some helpful alternative strategy for social enterprise? Some segments of the modern environmental movement and various social justice/equality organization appear to be adopting these techniques. Examining a sample of successful social enterprises in light of this club model is beyond the scope of this paper, but a worthy avenue of future research.

\section{Limitations and Extensions}

We have tested the application of the club model of public goods production as a strategy for mitigating free riding. We have argued that the model provides useful insights for social enterprise in general. Primarily, if an organization's membership is collective, where the 
value to members is contingent on the quality of other members' participation, then raising the cost of membership could lead to more sustainable production. This claim appears to be consistent with the history of the SBC. However, we are careful to note that this is just one organization.

Subsequent research effort is being put forth to collect additional data from a more wide variety of religious institutions. This included organizations that have experience more variation in their demand for sacrifice (i.e. main-line denominations such as United Methodist, Presbyterian Church (USA), or the American Baptist). These religious organization have relaxed religious restrictions earlier in their history and to a much greater degree than the SBC. Also, we would like to collect data on non-collective religious organizations, as described previously.

For reasons described above, we do think that the careful examination of religious organization can provide valuable information for social enterprise strategy. However, we do not want to overstate this comparison. Social enterprise represents a vast array of missions, markets, and operation models. Consequently, no single paper can pretend to unlock a universal principle for this type of institution. We do emphasize the need to empirical examination of social enterprise. With existing data limitations, religious institutions do provide a valuable, if imperfect starting point. 


\section{Works Cited}

Aguinis, H., \& Glavas, A. (2012). What We Know and Don' t Know About Corporate Social Responsibility. Journal of Management, 38(4), 932968. https://doi.org/10.1177/0149206311436079

Aimone, J. A., Iannaccone, L. R., Makowsky, M. D., \& Rubin, J. (2013). Endogenous Group Formation via Unproductive Costs. The Review of Economic Studies, 80(4), 1215- 1236. https://doi.org/10.1093/restud/rdt017

Andreoni, J. (1988). Why free ride?: Strategies and learning in public goods experiments. Journal of Public Economics, 37(3), 291- 304. https://doi.org/10.1016/0047-2727(88)90043-6

Andreoni, J. (1990). Impure Altruism and Donations to Public Goods: A Theory of Warm-Glow Giving? Economic Journal, 100(401), 464-77.

Andreoni, J. (2006). Philanthropy. In Serge-Christophe Kolm \& Jean Mercier Ythier (Eds.), Handbook of the Economics of Giving, Altruism and Reciprocity (Vol. 2, pp. 1201-1269). Elsevier. https://doi.org/10.1016/S1574-0714(06)02018-5

Andreoni, J., \& Payne, A. A. (2013). Charitable Giving. Handbook of Public Economics (Vol. 5). Elsevier B.V. https://doi.org/10.1016/B978-0-444-53759-1.00001-7

Austin, J., Stevenson, H., \& Wei-Skillern, J. (2006). Social and Commercial Entrepreneurship: Same, Different, or Both? Entrepreneurship Theory and Practice, 30(1), 1-22. https://doi.org/10.1111/j.15406520.2006.00107.x

Bagnoli, M., \& Watts, S. G. (2003). Selling to Socially Responsible Consumers: Competition and The Private Provision of Public Goods. Journal of Economics, 12(3), 419-445. https://doi.org/10.1111/j.14309134.2003.00419.x

Baker, R. A. (1974). The Southern Baptist Convention and its people, 1607-1972. Broadman Press.

Bekkers, R., \& Wiepking, P. (2011). A Literature Review of Empirical Studies of Philanthropy. Nonprofit and Voluntary Sector Quarterly, 4O(5), 924- 973. https://doi.org/10.1177/0899764010380927

Bergstrom, T., Blume, L., \& Varian, H. (1986). On the private provision of public goods. Journal of Public Economics, 29(1), 25- 49. https://doi.org/10.1016/0047-2727(86)90024-1

Berman, E. (2000). Sect, Subsidy, and Sacrifice: An Economist' s View of 
Ultra-Orthodox Jews. Quarterly Journal of Economics, 115(3), 905953. https://doi.org/10.1162/003355300554944

Berman, E. (2003). Hamas, Taliban and the Jewish underground: an economist' $s$ view of radical religious militias (No. 10004). National Bureau of Economic Research. Retrieved from http://www.nber.org/papers/w10004

Berman, E., \& Laitin, D. D. (2008). Relgion, Terrorism, and Public Goods: Testing the Club Model. Journal of Public Economics, 92(10), 19421967. https://doi.org/10.1016/j.jpubeco.2008.03.007

Bose, F., \& Komarek, T. M. (2015). Are Religion and Environmentalism Complements or Substitutes?: A Club-Based Approach. ISSN Interdisciplinary Journal of Research on Religion, 11, 1556-3723. Retrieved from http://www.religjournal.com.

Buchanan, J. M. (1965). An Economic Theory of Clubs. Economica, 32(125), 1. https://doi.org/10.2307/2552442

Cornes, R., \& Sandler, T. (1996). The Theory of Externalities, Public Goods, and Club Goods. Cambridge University Press. https://doi.org/10.1017/CBO9781139174312

Dacin, M. T., Dacin, P. A., \& Tracey, P. (2011). Social Entrepreneurship: A Critique and Future Directions. Organization Science, 22(5), 12031213. https://doi.org/10.1287/orsc. 1100.0620

Dawes, R. M., \& Thaler, R. H. (1988). Anomalies : Cooperation. Journal of Economic Perspectives, 2(3), 187- 197.

Defourny, J., \& Nyssens, M. (2010). Conceptions of Social Enterprise and Social Entrepreneurship in Europe and the United States: Convergences and Divergences. Journal of Social Entrepreneurship, 1(1), 32-53. https://doi.org/10.1080/19420670903442053

Ekelund, R., Hé bert, R., \& Tollison, R. (2006). The marketplace of Christianity. Camnbridge: MIT Press.

Elkington, J., \& Hartigan, P. (2008). The power of unreasonable people: how social entrepreneurs create markets that change the world. Harvard Business School Press.

Esposito, R., \& Pelsinger, S. (2014). People, Planet, Profit ... Religion. Stanford Social Innovation Review. Retrieved from https://ssir.org/articles/entry/people planet profit...religion Finke, R., \& Stark, R. (2005). The Churching of America, 1776-2005:

Winners and losers in our religious economy. Rutgers University Press. 
Retrieved from

https://books.google.com/books?hl=en\&lr=\&id=CUu34waWUMoC\&o

$\mathrm{i}=$ fnd\&pg $=\mathrm{PR} 5 \& \mathrm{dq}=$ The + churching + of + america\&ots $=1$ sn-

bRUeuB\&sig=JuEMEkbqtUU528j1W71TBnh10xY

Fischbacher, U., \& Gächter, S. (2010). Social Preferences, Beliefs, and the

Dynamics of Free Riding in Public Goods Experiments. American

Economic Review, 100(1), 541-556.

https://doi.org/10.1257/aer.100.1.541

Gerber, A. S., Gruber, J., \& Hungerman, D. M. (2016). Does Church

Attendance Cause People to Vote? Using Blue Laws' Repeal to

Estimate the Effect of Religiosity on Voter Turnout. British Journal of

Political Science British Journal of Political Science British Journal of

Political ScienceJ.Pol.S, 4678(46), 481-500.

https://doi.org/10.1017/S0007123414000416

Gneezy, A., Gneezy, U., Riener, G., \& Nelson, L. D. (2012). Pay-what-youwant, identity, and self-signaling in markets. Proceedings of the

National Academy of Sciences of the United States of America, 109(19), 7236-40. https://doi.org/10.1073/pnas.1120893109

Gruber, J. (2005). Public finance and public policy. Worth Publishers.

Gruber, J., \& Hungerman, D. M. (2006). The Church v.s the Mall: What

Happens When Religion Faces Increased Secular Competition? NBER

WORKING PAPER SERIES. Retrieved from

http://www.nber.org/papers/w12410

Gruber, J., \& Hungerman, D. M. (2008). The Church versus the Mall :

What Happens When Religion Faces Increased Secular Competition.

The Quarterly Journal of Economics, 123(2), 831-862.

Hamilton, B. H. (2000). Does Entrepreneurship Pay? An Empirical Analysis of the Returns to Self-Employment. Journal of Political Economy, 108(3), 604-631. https://doi.org/10.1086/262131

Hand, M. (2016). The Research Gap in Social Entrepreneurship. Stanford

Social Innovation Review, May, 2-5. Retrieved from

https://ssir.org/articles/entry/the'research'gap in 'social'entrepreneursh ip

Hausman, J. (1981). Exact Consumer's Surplus and Deadweight Loss.

American Economic Review, 71(4), 662-676. Retrieved from 
http://www.jstor.org/stable/1806188? seq=1\#page scan "tab" contents Hungerman, D. (2010). Rethinking the study of religious markets. In

Handbook of the Economics of Religion (pp. 257-275). Oxford: Oxford University Press. Retrieved from

https://www3.nd.edu/ dhungerm/Hungerman Chapter.pdf

Hungerman, D. M. (2014). Do Religious Proscriptions Matter? Evidence

from a Theory-Based Test. Journal of Human Resources, 49(4), 10531093. https://doi.org/10.3386/w17375

Iannaccone, L. R. (1992). Sacrifice and Stigma: Reducing Free-riding in

Cults, Communes, and Other Collectives. Journal of Political

Economy, 100(2), 271-291. https://doi.org/10.1086/261818

Iannaccone, L. R., \& Bose, F. (2012). Funding the Faiths: Toward a

Theory of Religious Finance. The Oxford Handbook of the Economics

of Religion. https://doi.org/10.1093/oxfordhb/9780195390049.013.0017

Iyer, S. (2016). The New Economics of Religion. Journal of Economic

Literature, 54(2), 395-441. https://doi.org/10.1257/jel.54.2.395

James Andreoni, \& A. Abigail Payne. (2008). Crowding out Both Sides of

the Philanthropy Market: Evidence from a Panel of Charities February

2008 By James Andreoni and A. Abigail Payne*. Levine's

Bibliography, (February). Retrieved from

http://www2.warwick.ac.uk/fac/soc/economics/news/forums/conferen ces/peuk/andreoni payne2 feb $25 \cdot 2008$.pdf

Kitzmueller, M., \& Shimshack, J. (2012). Economic Perspectives on

Corporate Social Responsibility. Journal of Economic Literature, 50(1), 51-84. https://doi.org/10.1257/jel.50.1.51

Laurence, R. (1992). Sacrifice and Stigma : Reducing Free-riding in Cults, Communes, and Other Collectives Author ( $\mathrm{s}$ ): Laurence R .

Iannaccone Source: Journal of Political Economy, Vol . 100 , No . 2 (

Apr ., 1992 ), pp . 271-291 Published by: The University of Chicago.

Journal of Political Economy, 100(2), 271-291.

Lindner, E. (2012). Yearbook of American \& Canadian Churches. Abingdon Press.

Manning, R., Markusen, J. R., McMillan, J., Manning, R., Markusen, J., \& McMillan, J. (1985). Paying for Public Inputs. American Economic

Review, 75(1), 235-38.

Marquis, C., \& Park, A. (2014). Inside the Buy-One Give-One Model. 
Stanford Social Innovation Review, (Winter 2014), 28-33.

Mas-Colell, A., Whinston, M. D., \& Green, J. R. (1995). Microeconomic theory. Oxford University Press. Retrieved from https://books.google.com/books/about/Microeconomic ‘Theory.html?id $=\mathrm{KGtegVXqD} 8 \mathrm{wC}$

McKeever, B. (2015). The Nonprofit Sector in Brief. The Non-Profit Sector in Brief 2015, 2007(October), 1-16. Retrieved from http://nonprofitaustin.org/wp-content/uploads/2012/10/412434NonprofitAlmanacBrief2011.pdf

Mckeever, B. S. (2015). The Nonprofit Sector in Brief 2015: Public Charities, Giving, and Volunteering. Retrieved from http://www.urban.org/sites/default/files/alfresco/publicationpdfs/2000497-The-Nonprofit-Sector-in-Brief-2015-Public-CharitiesGiving-and-Volunteering.pdf

Oster, S. M. (1995). Strategic Management for Nonprofit Organizations : Theory and Cases. Oxford University Press.

Powell, W. W., \& Steinberg, R. (2006). The nonprofit sector : a research handbook. Yale University Press. Retrieved from https://www.jstor.org/stable/j.ctt5vktdq

Roundy, P. T., \& Taylor, V. A. (2016). Founded by Faith: Social Entrepreneurship as a Bridge between Religion and Work. Journal of Ethics \& Entrepreneurship, 6(1), 13-37.

Samuelson, P. A. (1954). The Pure Theory of Public Expenditure. The Review of Economics and Statistics, 36(4), 387. https://doi.org/10.2307/1925895

Santos, F. E. M. (2012). A Positive Theory of Social Entrepreneurship. Journal of Business Ethics, 111(3), 335-351. https://doi.org/10.1007/s10551-012-1413-4

Smietana, B. (2015, August). Southern Baptists Will Cut 600 to 800 Missionaries and Staff. Christianity Today, web only. Retrieved from http://www.christianitytoday.com/ct/2015/august-web-only/southernbaptists-will-cut-800-missionaries-imb-david-platt.html

Stark, R. (1996). Why religious movements succeed or fail: A revised general model. Journal of Contemporary Religion, 11(2), 133-146. https://doi.org/10.1080/13537909608580764

Stark, R. (2015). 1 . The Rise of a New World Faith — Religious Studies 
Center.

US Supreme Court. Burwell v. Hobby Lobby (2013).

Varian, H. R. (2014). Intermediate Microeconoimcs. New York: W.W. Norton.

Zaleski, P. A., \& Zech, C. E. (1992). Determinants of Contributions to Religious Organizations: Free Riding and Other Factors. American Journal of Economics and Sociology, 51(4), 459-472. https://doi.org/10.1111/j.1536-7150.1992.tb02729.x

Zaleski, P. A., \& Zech, C. E. (1995). The Effect of Religious Market Competition on Church Giving. Review of Social Economy, 53(3), 350-367. https://doi.org/Article 


\section{INFLATION ADJUSTED CONTRIBUTIONS TO SBC OVER TIME}

$$
=\text { = Cooperative Program_Real* } \quad==\mathbf{=}=\text { : Lottie Moon_Real* }
$$

\section{$\$ 160,000,000$}

$\$ 140,000,000$

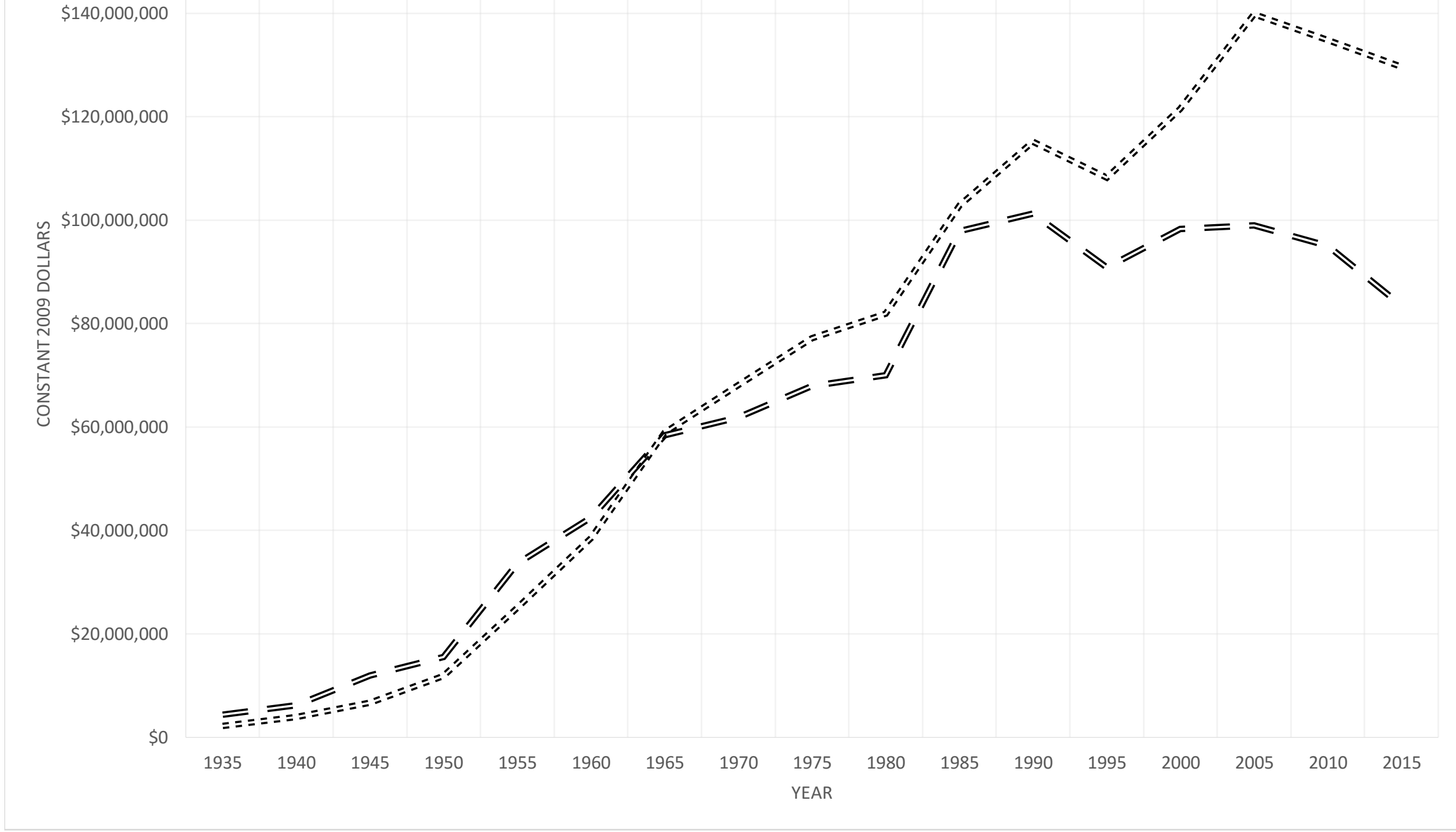




\begin{tabular}{ccccccc}
\hline \multicolumn{2}{c}{ Table 1: Real Trends in contributions to Cooperative Program and Lottie Moon } & & \\
\hline Year & CP_Nominal & LM_Nominal & $\begin{array}{c}\text { Cooperative } \\
\text { Program_Real* }\end{array}$ & $\begin{array}{c}\text { Lottie } \\
\text { Moon_Real* }\end{array}$ & $\begin{array}{c}\text { Avg \% Annual Avg \% Annual } \\
\text { Change Real } \\
\text { CP }\end{array}$ & $\begin{array}{c}\text { Change Real } \\
\text { LM }\end{array}$ \\
\hline 1935 & $\$ 338,027$ & $\$ 170,390$ & $\$ 4,379,158$ & $\$ 2,207,415$ & & \\
1940 & $\$ 490,460$ & $\$ 310,553$ & $\$ 6,224,113$ & $\$ 3,941,025$ & $8 \%$ & $16 \%$ \\
1945 & $\$ 1,357,584$ & $\$ 761,033$ & $\$ 12,010,829$ & $\$ 6,733,016$ & $19 \%$ & $14 \%$ \\
1950 & $\$ 2,201,287$ & $\$ 1,672,547$ & $\$ 15,582,126$ & $\$ 11,839,364$ & $6 \%$ & $15 \%$ \\
1955 & $\$ 5,308,927$ & $\$ 3,964,437$ & $\$ 33,602,931$ & $\$ 25,092,962$ & $23 \%$ & $22 \%$ \\
1960 & $\$ 7,463,141$ & $\$ 6,758,025$ & $\$ 42,561,397$ & $\$ 38,540,205$ & $5 \%$ & $11 \%$ \\
1965 & $\$ 10,900,000$ & $\$ 11,000,000$ & $\$ 58,385,559$ & $\$ 58,921,206$ & $7 \%$ & $11 \%$ \\
1970 & $\$ 13,800,000$ & $\$ 15,200,000$ & $\$ 61,852,898$ & $\$ 68,127,829$ & $1 \%$ & $3 \%$ \\
1975 & $\$ 20,600,000$ & $\$ 23,400,000$ & $\$ 67,919,552$ & $\$ 77,151,335$ & $2 \%$ & $3 \%$ \\
1980 & $\$ 30,800,000$ & $\$ 36,000,000$ & $\$ 70,065,288$ & $\$ 81,894,493$ & $1 \%$ & $1 \%$ \\
1985 & $\$ 55,400,000$ & $\$ 58,200,000$ & $\$ 97,910,996$ & $\$ 102,859,567$ & $8 \%$ & $5 \%$ \\
1990 & $\$ 68,300,000$ & $\$ 77,700,000$ & $\$ 101,275,208$ & $\$ 115,213,523$ & $1 \%$ & $2 \%$ \\
1995 & $\$ 69,400,000$ & $\$ 82,600,000$ & $\$ 90,890,041$ & $\$ 108,177,484$ & $-2 \%$ & $-1 \%$ \\
2000 & $\$ 81,700,000$ & $\$ 101,000,000$ & $\$ 98,278,620$ & $\$ 121,494,990$ & $2 \%$ & $2 \%$ \\
2005 & $\$ 91,300,000$ & $\$ 129,000,000$ & $\$ 98,958,390$ & $\$ 139,820,726$ & $0 \%$ & $3 \%$ \\
2010 & $\$ 96,600,000$ & $\$ 137,000,000$ & $\$ 95,029,168$ & $\$ 134,772,215$ & $-1 \%$ & $-1 \%$ \\
2015 & $\$ 91,500,000$ & $\$ 142,000,000$ & $\$ 83,537,231$ & $\$ 129,642,479$ & $-2 \%$ & $-1 \%$ \\
\hline
\end{tabular}

Notes:

DPCERD3A086NBEA

Personal consumption expenditures (implicit price deflator), Index 2009=100,

Annual, Not Seasonally Adjusted

* 2009 Dollars 


\begin{tabular}{|c|c|c|c|c|c|c|c|c|c|c|c|c|c|c|c|c|c|}
\hline State & 1935 & 1940 & 1945 & 1950 & 1955 & 1960 & 1965 & 1970 & 1975 & 1980 & 1985 & 1990 & 1995 & 2000 & 2005 & 2010 & 2015 \\
\hline Texas & $\$ 22,082$ & $\$ 60,858$ & $\$ 113,277$ & $\$ 241,096$ & $\$ 989,846$ & $\$ 1,437,043$ & $\$ 1,837,603$ & $\$ 2,296,876$ & $\$ 3,426,390$ & $\$ 5,316,293$ & $\$ 9,786,000$ & \#\#\#\#\#\#\#\# & \#\#\#\#\#\#\#\# & \#\#\#\#\#\#\#\# & \#\#\#\#\#\#\#\# & 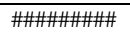 & \#\#\#\#\#\#\# \\
\hline Georgia & $\$ 11,326$ & $\$ 32,247$ & $\$ 93,576$ & $\$ 157,638$ & $\$ 415,116$ & $\$ 632,830$ & $\$ 1,022,871$ & $\$ 1,338,341$ & $\$ 1,853,057$ & $\$ 2,552,643$ & $\$ 4,675,000$ & $\$ 7,862,848$ & $\$ 7,267,189$ & $\$ 9,096,831$ & \#\#\#\#\#\#\#\# & $\$ 9,808,252$ & $\$ 8,508,358$ \\
\hline Alabama & $\$ 18,901$ & $\$ 25,245$ & $\$ 58,268$ & $\$ 112,547$ & $\$ 249,315$ & $\$ 471,983$ & $\$ 689,929$ & $\$ 901,768$ & $\$ 1,464,579$ & $\$ 2,071,264$ & $\$ 3,770,000$ & $\$ 5,191,159$ & $\$ 6,047,446$ & $\$ 7,787,857$ & $\$ 8,172,579$ & $\$ 9,499,485$ & $\$ 8,630,313$ \\
\hline Florida & $\$ 12,757$ & $\$ 19,128$ & $\$ 56,394$ & $\$ 117,166$ & $\$ 281,304$ & $\$ 413,491$ & $\$ 679,679$ & $\$ 974,180$ & $\$ 1,561,710$ & $\$ 2,009,664$ & $\$ 4,377,000$ & $\$ 5,364,491$ & $\$ 4,979,271$ & $\$ 5,789,534$ & $\$ 7,083,455$ & $\$ 6,987,742$ & $\$ 6,123,790$ \\
\hline Tennessee & $\$ 36,616$ & $\$ 51,467$ & $\$ 148,334$ & $\$ 212,805$ & $\$ 416,787$ & $\$ 558,984$ & $\$ 701,823$ & $\$ 901,243$ & $\$ 1,280,441$ & $\$ 1,976,365$ & $\$ 3,352,000$ & $\$ 4,341,631$ & $\$ 4,809,197$ & $\$ 6,319,007$ & $\$ 6,988,282$ & $\$ 7,578,115$ & $\$ 7,062,514$ \\
\hline South Carolina & $\$ 33,549$ & $\$ 44,030$ & $\$ 116,952$ & $\$ 207,875$ & $\$ 447,804$ & $\$ 464,434$ & $\$ 759,149$ & $\$ 879,306$ & $\$ 1,228,074$ & $\$ 1,832,727$ & $\$ 3,096,000$ & $\$ 4,163,908$ & $\$ 4,370,444$ & $\$ 5,625,051$ & $\$ 6,442,857$ & $\$ 5,960,987$ & $\$ 5,631,280$ \\
\hline North Carolina & $\$ 33,055$ & $\$ 53,120$ & $\$ 120,948$ & $\$ 204,145$ & $\$ 420,686$ & $\$ 582,247$ & $\$ 852,500$ & $\$ 1,131,842$ & $\$ 1,609,186$ & $\$ 2,417,208$ & $\$ 3,890,000$ & $\$ 4,518,728$ & $\$ 3,923,131$ & $\$ 4,469,208$ & $\$ 4,917,369$ & $\$ 5,037,345$ & $\$ 5,273,277$ \\
\hline Mississippi & $\$ 13,548$ & $\$ 13,560$ & $\$ 64,599$ & $\$ 106,035$ & $\$ 229,794$ & $\$ 328,686$ & $\$ 484,883$ & $\$ 636,933$ & $\$ 933,839$ & $\$ 1,492,085$ & $\$ 2,811,000$ & $\$ 3,481,663$ & $\$ 4,125,904$ & $\$ 4,515,962$ & $\$ 5,477,357$ & $\$ 6,000,189$ & $\$ 5,768,968$ \\
\hline Oklahoma & $\$ 885$ & $\$ 10,875$ & $\$ 59,931$ & $\$ 102,429$ & $\$ 333,432$ & $\$ 437,476$ & $\$ 580,335$ & $\$ 704,382$ & $\$ 1,160,546$ & $\$ 1,837,488$ & $\$ 3,706,000$ & $\$ 3,434,052$ & $\$ 3,636,436$ & $\$ 3,904,818$ & $\$ 4,457,152$ & $\$ 4,993,859$ & $\$ 5,249,593$ \\
\hline Kentucky & $\$ 37,542$ & $\$ 52,218$ & $\$ 141,841$ & $\$ 166,391$ & $\$ 259,216$ & $\$ 325,700$ & $\$ 534,330$ & $\$ 587,188$ & $\$ 786,842$ & $\$ 1,399,940$ & $\$ 2,424,000$ & $\$ 3,291,450$ & $\$ 3,341,243$ & $\$ 3,626,865$ & $\$ 3,800,390$ & $\$ 4,330,007$ & $\$ 4,900,215$ \\
\hline Louisiana & $\$ 7,116$ & $\$ 11,526$ & $\$ 60,999$ & $\$ 79,129$ & $\$ 240,278$ & $\$ 364,732$ & $\$ 448,232$ & $\$ 571,236$ & $\$ 800,224$ & $\$ 1,459,425$ & $\$ 2,540,000$ & $\$ 2,590,934$ & $\$ 2,985,122$ & $\$ 3,617,129$ & $\$ 3,921,137$ & $\$ 4,402,362$ & $\$ 3,841,547$ \\
\hline Arkansas & $\$ 3,940$ & $\$ 11,097$ & $\$ 39,153$ & $\$ 85,048$ & $\$ 191,195$ & $\$ 251,467$ & $\$ 367,658$ & $\$ 443,207$ & $\$ 774,482$ & $\$ 1,139,230$ & $\$ 2,038,000$ & $\$ 2,651,350$ & $\$ 3,208,455$ & $\$ 3,628,205$ & $\$ 3,936,523$ & $\$ 4,152,773$ & $\$ 4,500,161$ \\
\hline Virginia & $\$ 80,671$ & $\$ 60,858$ & $\$ 157,229$ & $\$ 186,891$ & $\$ 287,799$ & $\$ 432,429$ & $\$ 704,576$ & $\$ 843,565$ & $\$ 1,191,803$ & $\$ 1,464,272$ & $\$ 2,331,000$ & $\$ 2,938,747$ & $\$ 2,103,200$ & $\$ 2,146,888$ & $\$ 2,888,518$ & $\$ 3,338,765$ & $\$ 2,672,559$ \\
\hline Missouri & $\$ 11,487$ & $\$ 26,816$ & $\$ 69,096$ & $\$ 127,991$ & $\$ 269,542$ & $\$ 350,462$ & $\$ 516,459$ & $\$ 636,303$ & $\$ 892,666$ & $\$ 1,298,273$ & $\$ 2,193,000$ & $\$ 2,520,120$ & $\$ 2,655,017$ & $\$ 3,067,805$ & $\$ 3,152,780$ & $\$ 2,861,377$ & $\$ 2,843,186$ \\
\hline Illinois & $\$ 591$ & $\$ 3,073$ & $\$ 25,317$ & $\$ 35,924$ & $\$ 83,556$ & $\$ 94,972$ & $\$ 150,186$ & $\$ 203,770$ & $\$ 346,442$ & $\$ 568,479$ & $\$ 835,000$ & $\$ 901,651$ & $\$ 1,031,757$ & $\$ 1,232,444$ & $\$ 1,330,319$ & $\$ 1,217,596$ & $\$ 1,268,498$ \\
\hline California & & & $\$ 1,073$ & $\$ 4,953$ & $\$ 41,924$ & $\$ 69,686$ & $\$ 137,435$ & $\$ 166,586$ & $\$ 261,184$ & $\$ 381,729$ & $\$ 656,000$ & $\$ 798,441$ & $\$ 873,328$ & $\$ 1,012,300$ & $\$ 1,037,465$ & $\$ 1,106,097$ & $\$ 1,112,784$ \\
\hline Ohio & & & & & $\$ 3,697$ & $\$ 16,777$ & $\$ 56,319$ & $\$ 108,265$ & $\$ 188,188$ & $\$ 290,913$ & $\$ 494,000$ & $\$ 639,248$ & $\$ 719,260$ & $\$ 845,709$ & $\$ 898,117$ & $\$ 864,953$ & $\$ 894,726$ \\
\hline Maryland & $\$ 10,796$ & $\$ 8,451$ & $\$ 18,233$ & $\$ 19,918$ & $\$ 51,605$ & $\$ 75,991$ & $\$ 129,764$ & $\$ 154,901$ & $\$ 221,291$ & $\$ 284,408$ & $\$ 461,000$ & $\$ 593,467$ & $\$ 568,099$ & $\$ 671,246$ & $\$ 887,263$ & $\$ 927,869$ & $\$ 904,151$ \\
\hline New Mexico & $\$ 406$ & $\$ 724$ & $\$ 6,324$ & $\$ 14,535$ & $\$ 44,656$ & $\$ 56,083$ & $\$ 73,497$ & $\$ 80,000$ & $\$ 113,747$ & $\$ 182,214$ & $\$ 308,000$ & $\$ 369,430$ & $\$ 389,890$ & $\$ 448,362$ & $\$ 537,244$ & $\$ 614,270$ & $\$ 408,616$ \\
\hline Kansas/Nebraska & & & & $\$ 472$ & $\$ 7,078$ & $\$ 17,243$ & $\$ 14,714$ & $\$ 28,331$ & $\$ 49,332$ & $\$ 86,016$ & $\$ 177,000$ & $\$ 258,392$ & $\$ 284,789$ & $\$ 430,121$ & $\$ 498,542$ & $\$ 555,122$ & $\$ 316,955$ \\
\hline Arizona & $\$ 275$ & $\$ 412$ & $\$ 2,022$ & $\$ 6,238$ & $\$ 18,209$ & $\$ 19,058$ & $\$ 36,074$ & $\$ 37,809$ & $\$ 73,855$ & $\$ 135,723$ & $\$ 284,000$ & $\$ 378,495$ & $\$ 218,802$ & $\$ 308,330$ & $\$ 376,418$ & $\$ 426,352$ & $\$ 389,335$ \\
\hline Indiana & & & & & & $\$ 9,062$ & $\$ 24,863$ & $\$ 43,552$ & $\$ 91,257$ & $\$ 139,071$ & $\$ 214,000$ & $\$ 236,170$ & $\$ 286,000$ & $\$ 369,568$ & & $\$ 518,100$ & $\$ 374,996$ \\
\hline Colorado & & & & & & $\$ 12,768$ & $\$ 16,564$ & $\$ 20,617$ & $\$ 59,284$ & $\$ 104,619$ & $\$ 170,000$ & $\$ 140,871$ & $\$ 218,410$ & $\$ 250,305$ & $\$ 295,582$ & $\$ 307,034$ & $\$ 261,159$ \\
\hline & & & & & & $\$ 7,246$ & $\$ 20,086$ & $\$ 29,403$ & $\$ 40,455$ & $\$ 73,571$ & $\$ 106,000$ & $\$ 173,440$ & $\$ 185,878$ & & $\$ 262,757$ & $\$ 233,850$ & $\$ 121,992$ \\
\hline West Virginia & & & & & & & & $\$ 0$ & $\$ 16,289$ & $\$ 25,613$ & $\$ 50,000$ & $\$ 70,047$ & $\$ 98,806$ & $\$ 163,454$ & $\$ 221,078$ & $\$ 252,151$ & $\$ 229,640$ \\
\hline Hawaii & & & & & & $\$ 2,525$ & $\$ 7,451$ & $\$ 10,738$ & $\$ 20,188$ & $\$ 24,127$ & $\$ 57,000$ & $\$ 88,317$ & $\$ 126,545$ & $\$ 129,509$ & 9,095 & 7,170 & $\$ 183,718$ \\
\hline Alaska & & & & & $\$ 2,968$ & $\$ 2,353$ & $\$ 5,905$ & $\$ 11,859$ & $\$ 19,790$ & $\$ 30,203$ & $\$ 64,000$ & $\$ 79,269$ & $\$ 94,623$ & $\$ 90,428$ & $\$ 104,484$ & $\$ 114,234$ & $\$ 119,717$ \\
\hline Nevada & & & & & & & & & & $\$ 0$ & $\$ 31,000$ & $\$ 49,702$ & $\$ 70,617$ & $\$ 114,060$ & $\$ 135,497$ & $\$ 136,153$ & $\$ 157,199$ \\
\hline Penns & & & & & & & & & $\$ 21,187$ & $\$ 31,033$ & $\$ 52,000$ & $\$ 82,070$ & $\$ 70,718$ & $\$ 84,833$ & $\$ 102,264$ & & $\$ 102,803$ \\
\hline New $Y$ & & & & & & & & & $\$ 18,345$ & $\$ 22,946$ & $\$ 43,000$ & $\$ 68,156$ & $\$ 71,908$ & $\$ 76,612$ & $\$ 102,537$ & $\$ 113,588$ & $\$ 91,674$ \\
\hline District of Columbia & $\$ 2,484$ & $\$ 4,755$ & $\$ 4,017$ & $\$ 11,642$ & $\$ 17,708$ & $\$ 18,711$ & $\$ 28,555$ & $\$ 18,181$ & $\$ 43,021$ & $\$ 36,269$ & $\$ 49,000$ & $\$ 68,390$ & $\$ 37,253$ & $\$ 113,496$ & $\$ 101,737$ & $\$ 15,864$ & $\$ 8,111$ \\
\hline Oregon/Washington & & & & $\$ 420$ & $\$ 5,412$ & $\$ 8,706$ & $\$ 18,655$ & $\$ 28,660$ & $\$ 68,354$ & $\$ 133,303$ & $\$ 227,000$ & & & & & & \\
\hline Utah-Idaho & & & & & & & & $\$ 5,065$ & $\$ 11,250$ & $\$ 16,389$ & $\$ 33,000$ & $\$ 34,596$ & $\$ 20,603$ & $\$ 51,879$ & $\$ 73,745$ & $\$ 87,205$ & $\$ 70,046$ \\
\hline lew England & & & & & & & & & & & $\$ 27,000$ & $\$ 48,880$ & $\$ 58,228$ &, 372 & & 7,971 & $\$ 57,646$ \\
\hline Wyoming & & & & & & & & & & & $\$ 22,000$ & $\$ 31$ & 710 & $\$ 53,673$ & $\$ 70,273$ & $\$ 86,094$ & $\$ 62,723$ \\
\hline Minnesota/Wisconsin & & & & & & & & & & & $\$ 25,000$ & $\$ 36,809$ & $\$ 43,803$ & $\$ 57,517$ & $\$ 26,300$ & $\$ 31,265$ & $\$ 31,793$ \\
\hline Montana & & & & & & & & & & & & $\$ 18,343$ & $\$ 26,138$ & $\$ 34,578$ & $\$ 49,905$ & $\$ 51,084$ & $\$ 65,386$ \\
\hline Iowa & & & & & & & & & & & & $\$ 18,153$ & $\$ 31,446$ & $\$ 45,036$ & $\$ 46,028$ & $\$ 55,913$ & $\$ 47,240$ \\
\hline
\end{tabular}

Source: Southern Baptist Historical Library and Archives 


\begin{tabular}{|c|c|c|c|c|c|c|c|c|c|c|c|c|c|c|c|c|c|}
\hline 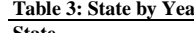 & & & & & & & & & & & & & & & & & \\
\hline 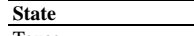 & 1935 & 1940 & 1945 & 1950 & 1955 & 1960 & 1965 & 1970 & 1975 & 1980 & 1985 & 1990 & 1995 & 2000 & 2005 & 2010 & 2015 \\
\hline Texas & $\$ 36,797$ & $\$ 62,143$ & $\$ 234,421$ & $\$ 533,026$ & $\$ 1,438,343$ & $\$ 2,063,919$ & $\$ 2,801,142$ & $\$ 3,426,613$ & $\$ 4,581,906$ & $\$ 6,672,384$ & $\$ 11,100,000$ & $\$ 12,900,000$ & $\$ 13,600,000$ & $\$ 14,600,000$ & $\$ 19,700,000$ & $\$ 21,400,000$ & $\$ 22,300,000$ \\
\hline North Carolina & $\$ 14,188$ & $\$ 39,093$ & $\$ 75,682$ & $\$ 158,172$ & $\$ 345,538$ & $\$ 620,725$ & $\$ 1,119,144$ & $\$ 1,577,996$ & $\$ 2,455,274$ & $\$ 3,741,796$ & $\$ 6,478,000$ & $\$ 9,004,020$ & $\$ 9,054,222$ & $\$ 11,000,000$ & $\$ 13,200,000$ & $\$ 14,900,000$ & $\$ 13,700,000$ \\
\hline Georgia & $\$ 9,425$ & $\$ 18,565$ & $\$ 42,286$ & $\$ 86,427$ & $\$ 198,971$ & $\$ 408,783$ & $\$ 738,967$ & $\$ 1,134,676$ & $\$ 1,641,096$ & $\$ 2,546,191$ & $\$ 4,420,000$ & $\$ 6,696,433$ & $\$ 6,952,087$ & $\$ 8,683,521$ & $\$ 11,600,000$ & $\$ 11,700,000$ & $\$ 12,000,000$ \\
\hline Alabama & $\$ 6,797$ & $\$ 13,571$ & $\$ 29,993$ & $\$ 72,168$ & $\$ 170,278$ & $\$ 341,434$ & $\$ 589,850$ & $\$ 916,692$ & $\$ 1,540,903$ & $\$ 2,520,531$ & $\$ 3,944,000$ & $\$ 5,820,187$ & $\$ 6,711,133$ & $\$ 8,110,818$ & $\$ 10,900,000$ & $\$ 11,600,000$ & $\$ 12,500,000$ \\
\hline Tennessee & $\$ 8,589$ & $\$ 19,258$ & $\$ 35,090$ & $\$ 77,364$ & $\$ 173,294$ & $\$ 377,798$ & $\$ 679,730$ & $\$ 1,009,777$ & $\$ 1,589,694$ & $\$ 2,544,214$ & $\$ 3,921,000$ & $\$ 5,909,125$ & $\$ 6,572,871$ & $\$ 7,839,044$ & $\$ 11,000,000$ & $\$ 11,000,000$ & $\$ 11,900,000$ \\
\hline Mississippi & $\$ 8,802$ & $\$ 14,212$ & $\$ 37,153$ & $\$ 76,081$ & $\$ 170,714$ & $\$ 321,670$ & $\$ 528,600$ & $\$ 800,502$ & $\$ 1,301,661$ & $\$ 2,237,460$ & $\$ 3,632,000$ & $\$ 4,747,519$ & $\$ 5,543,059$ & $\$ 11,500,000$ & $\$ 8,099,894$ & $\$ 8,885,779$ & $\$ 9,859,931$ \\
\hline South Carolina & $\$ 9,979$ & $\$ 21,644$ & $\$ 44,345$ & $\$ 96,409$ & $\$ 215,754$ & $\$ 374,843$ & $\$ 701,757$ & $\$ 1,059,332$ & $\$ 1,661,606$ & $\$ 2,446,291$ & $\$ 3,607,000$ & $\$ 5,339,971$ & $\$ 5,514,302$ & $\$ 6,783,387$ & $\$ 8,424,691$ & $\$ 8,413,190$ & $\$ 8,455,741$ \\
\hline Florida & $\$ 3,565$ & $\$ 7,598$ & $\$ 22,031$ & $\$ 50,293$ & 36,265 & $\$ 290,853$ & $\$ 555,312$ & $\$ 814,037$ & $\$ 1,438,599$ & $\$ 2,116,685$ & $\$ 3,412,000$ & $\$ 4,192,099$ & $\$ 4,267,349$ & $\$ 5,178,410$ & $\$ 6,977$, & $\$ 6,590,858$ & $\$ 6,117,859$ \\
\hline Virginia & $\$ 26,241$ & $\$ 41,071$ & $\$ \$ 80,703$ & $\$ 151,026$ & $\$ 226,844$ & $\$ 322,236$ & $\$ 485,215$ & $\$ 651,184$ & $\$ 1,065,056$ & $\$ 1,631,272$ & $\$ 2,582,000$ & $\$ 3,902,926$ & $\$ 3,945,694$ & $\$ 4,474,905$ & $\$ 6,423,859$ & $\$ 6,675,756$ & $\$ 6,886,210$ \\
\hline Oklahoma & $\$ 6,190$ & $\$ 12,909$ & $\$ 30,231$ & $\$ 79,327$ & $\$ 163,667$ & $\$ 271,338$ & $\$ 553,335$ & $\$ 599,739$ & $\$ 976,327$ & $\$ 1,525,994$ & $\$ 2,568,000$ & $\$ 2,541,423$ & $\$ 2,921,721$ & $\$ 3,482,039$ & $\$ 4,634,123$ & $\$ 5,274,238$ & $\$ 6,013,547$ \\
\hline Arkansas & $\$ 10,284$ & $\$ 8,889$ & $\$ 22,904$ & $\$ 51,990$ & $\$ 113,983$ & $\$ 190,393$ & $\$ 297,839$ & $\$ 423,294$ & $\$ 759,327$ & $\$ 1,146,976$ & $\$ 1,977,000$ & $\$ 2,814,433$ & $\$ 2,941,839$ & $\$ 2,833,624$ & $\$ 5,269,520$ & $\$ 5,661,870$ & $\$ 5,593,660$ \\
\hline Louisiana & $\$ 4,019$ & $\$ 11,701$ & $\$ 28,401$ & $\$ 63,943$ & $\$ 184,858$ & $\$ 322,686$ & $\$ 436,810$ & $\$ 608,189$ & $\$ 897,003$ & $\$ 1,475,067$ & $\$ 2,295,000$ & $\$ 2,520,004$ & $\$ 2,714,442$ & $\$ 3,265,955$ & $\$ 3,819,963$ & $\$ 5,021,315$ & $\$ 5,945,379$ \\
\hline Kentucky & $\$ 11,507$ & $\$ 18,689$ & $\$ 33,094$ & $\$ 66,339$ & $\$ 127,589$ & $\$ 228,462$ & $\$ 365,795$ & $\$ 488,707$ & $\$ 767,324$ & $\$ 1,238,183$ & $\$ 1,858,000$ & $\$ 2,638,551$ & $\$ 2,862,395$ & $\$ 3,257,941$ & $\$ 4,633,454$ & $\$ 5,005,676$ & $\$ 5,258,771$ \\
\hline Missouri & $\$ 9,182$ & $\$ 12,629$ & $\$ 26,083$ & $\$ 60,382$ & $\$ 145,752$ & $\$ 265,185$ & $\$ 407,758$ & $\$ 541,380$ & $\$ 802,309$ & $\$ 1,226,207$ & $\$ 1,717,000$ & $\$ 2,600,593$ & & $\$ 3,232,978$ & & & $\$ 4,160,550$ \\
\hline California & & & $\$ 942$ & $\$ 5,607$ & $\$ 31,551$ & $\$ 85,809$ & $\$ 174,543$ & $\$ 255,110$ & $\$ 406,488$ & $\$ 602,502$ & $\$ 918,000$ & $\$ 1,252,479$ & $\$ 1,150,830$ & $\$ 1,402,808$ & & & $\$ 1,841,759$ \\
\hline Illinois & $\$ 1,453$ & $\$ 2,992$ & $\$ 6,492$ & $\$ 18,867$ & $\$ 35,846$ & $\$ 74,718$ & $\$ 126,001$ & $\$ 183,694$ & $\$ 278,822$ & $\$ 432,634$ & $\$ 593,000$ & $\begin{array}{l}\$ 784,789 \\
\end{array}$ & $\$ 788,843$ & $\$ 862,772$ & $\$ 1,109,222$ & $\$ 1,320,858$ & $\$ 1,322,932$ \\
\hline Maryland & $\$ 1,835$ & $\$ 2,248$ & $\$ 3,724$ & $\$ 6,580$ & $\$ 15,107$ & $\$ 35,883$ & $\$ 80,031$ & $\$ 139,015$ & $\$ 215,007$ & $\$ 291,880$ & $\$ 382,000$ & $\$ 579,449$ & $\$ 564,236$ & $\$ 634,701$ & $\$ 997,469$ & $\$ 923,994$ & $\$ 1,036,796$ \\
\hline Ohio & & & & & $\$ 1,836$ & $\$ 9,745$ & $\$ 53,373$ & $\$ 104,805$ & $\$ 172,392$ & $\$ 267,128$ & $\$ 365,000$ & $\$ 447,278$ & $\$ 663,162$ & $\$ 700,604$ & $\$ 999,184$ & $\$ 863,470$ & $\$ 991,705$ \\
\hline New Mexico & $\$ 691$ & $\$ 1,792$ & $\$ 4,488$ & $\$ 13,187$ & $\$ 29,403$ & $\$ 60,676$ & $\$ 88,406$ & $\$ 100,931$ & $\$ 151,945$ & $\$ 238,653$ & $\$ 457,000$ & $\$ 513,217$ & $\$ 537,079$ & $\$ 557,065$ & $\$ 807,045$ & $\$ 1,023,218$ & $\$ 1,008,475$ \\
\hline Arizona & $\$ 177$ & $\$ 462$ & $\$ 1,222$ & $\$ 1,300$ & $\$ 19,458$ & $\$ 18,611$ & $\$ 55,409$ & $\$ 63,920$ & $\$ 107,850$ & $\$ 196,279$ & $\$ 303,000$ & $\$ 468,140$ & $\$ 495,846$ & $\$ 470,480$ & $\$ 766,292$ & $\begin{array}{r}\$ 760,708 \\
\end{array}$ & $\$ 750,950$ \\
\hline Kansas/Neb & & & & $\$ 607$ & $\$ 5,625$ & $\$ 17,822$ & & & $\$ 98,695$ & & & & & & & & $\$ 590,496$ \\
\hline Colorado & & & & & & $\$ 14,680$ & $\$ 39,657$ & $\$ 39,746$ & $\$ 119,012$ & $\$ 206$, & $\$ 262$ & & $\$ 35$ & & & & $\$ 727,228$ \\
\hline Indiana & & & & & & $\$ 4,912$ & $\$ 23,6$ & $\$ 42,330$ & $\$ 88,698$ & $\$ 144$ & $\$ 191$, & & & $\$ 366$ & & & $\$ 504,785$ \\
\hline Michigan & & & & & & $\$ 763$ & $\$ \$ 10,622$ & $\$ 32,244$ & $\$ 31,678$ & $\$ 70,000$ & $\$ 97,000$ & $\$ 134,972$ & $\$ 139,222$ & $\$ 172,758$ & $\$ 245$, & $\$ 263,763$ & $\$ 167,023$ \\
\hline New York & & & & & & & & & $\$ 38,243$ & $\$ 79$, & $\$ 100,000$ & & & & & & $\$ 241,557$ \\
\hline Hawaii & & & & & & $\$ 0$ & $\$ 15,015$ & $\$ 21,762$ & $\$ 29,504$ & $\$ 35,631$ & $\$ 57,000$ & $\$ 101,329$ & $\$ 120,556$ & $\$ 131,333$ & $\$ 206,065$ & $\$ 183,454$ & $\$ 264,470$ \\
\hline Pennsylvania & & & & & & & & & $\$ 33,601$ & $\$ 45,365$ & $\$ 78,000$ & $\$ 121,593$ & $\$ 117,478$ & $\$ 146,166$ & $\$ 218,762$ & $\$ 196,611$ & $\$ 197,901$ \\
\hline West Vir & & & & & & & & $\$ 1,289$ & $\$ 19,101$ & $\$ 33,608$ & $\$ 57,000$ & & & & & $\$ 267,036$ & $\$ 215,797$ \\
\hline Alaska & & & & & $\$ 218$ & $\$ 3,719$ & $\$ 8,230$ & $\$ 11,287$ & $\$ 25,816$ & $\$ 36$, & $\$ 85$, & $\$ 117$ & & & & & $\$ 104,646$ \\
\hline Utah-Idaho & & & & & & & & $\$ 8,605$ & $\$ 17,601$ & $\$ 27,316$ & & & & & & & 5,519 \\
\hline Nevada & & & & & & & & & & & $\$ 44$ & & & & & $\$ 227,979$ & $\$ 146,909$ \\
\hline District of Columbia & $\$ 670$ & $\$ 1,086$ & $\$ 1,748$ & $\$ 3,453$ & $\$ 6,422$ & $\$ 12,798$ & $\$ 29,194$ & $\$ 32,756$ & $\$ 36,592$ & $\$ 47,672$ & $\$ 54,000$ & $\$ 68,249$ & $\$ 68,091$ & $\$ 54,771$ & $\$ 85,052$ & $\$ 80,746$ & $\$ 175,944$ \\
\hline New England & & & & & & & & & & & $\$ 48,000$ & $\$ 87,079$ & $\$ 78,067$ & $\$ 90,402$ & $\$ 23,285$ & $\$ 1,175$ & $\$ 310,782$ \\
\hline Minnesota/Wisconsin & & & & & & & & & & & $\$ 34,000$ & $\$ 52,346$ & $\$ 53,785$ & $\$ 64,720$ & $\$ 98,955$ & $\$ 120,193$ & $\$ 153,015$ \\
\hline Opa & & & & $\$ 0$ & $\$ 7,120$ & $\$ 17,564$ & $\$ 33,856$ & $\$ 48,701$ & $\$ 45,535$ & $\$ 161,263$ & $\$ 247,000$ & & & & & & \\
\hline $0 r$ & & & & & & & & & & & $\$ 29,000$ & $\$ 46,751$ & & 738 & $\$ 99,822$ & $\$ 108,167$ & $\$ 111,102$ \\
\hline & & & & & & & & & & & & & & & & & $\$ 131$ \\
\hline & & & & & & & & & & & & $\$ 4,064$ & $\$ 47,997$ & $\$ 53,220$ & $\$ 81,976$ & $\$ 93,808$ & $\$ 120,357$ \\
\hline
\end{tabular}

Source: Southern Baptist Historical Library and Archives 


\begin{tabular}{|c|c|c|c|c|c|}
\hline STATE & CHURCHES & TRANSFERS & $\begin{array}{c}\text { PER CAPITA } \\
\text { INCOME }\end{array}$ & $\begin{array}{c}\text { STATE } \\
\text { POPULATION }\end{array}$ & $\begin{array}{c}\text { RACE (Percent } \\
\text { Black) }\end{array}$ \\
\hline Alabama & 2,829 & $\$ 9,607,950$ & $\$ 11,536$ & $3,716,191$ & $28 \%$ \\
\hline Alaska & 49 & $\$ 1,792,440$ & $\$ 22,087$ & 480,014 & $3 \%$ \\
\hline Arizona & 199 & $\$ 10,800,000$ & $\$ 12,483$ & $2,854,536$ & $3 \%$ \\
\hline Arkansas & 1,170 & $\$ 6,002,863$ & $\$ 11,006$ & $2,227,966$ & $19 \%$ \\
\hline California & 890 & $\$ 77,900,000$ & $\$ 17,946$ & $24,500,000$ & $6 \%$ \\
\hline Colorado & 214 & $\$ 10,200,000$ & $\$ 20,814$ & $3,439,963$ & $4 \%$ \\
\hline District of Colu & 64 & $\$ 1,544,427$ & $\$ 20,656$ & 685,683 & $53 \%$ \\
\hline Florida & 1,430 & $\$ 37,400,000$ & $\$ 14,007$ & $9,453,992$ & $18 \%$ \\
\hline Georgia & 2,908 & $\$ 14,900,000$ & $\$ 12,681$ & $5,681,195$ & $29 \%$ \\
\hline Hawaii & 51 & $\$ 3,253,048$ & $\$ 20,928$ & $1,050,296$ & $2 \%$ \\
\hline Illinois & 799 & $\$ 24,600,000$ & $\$ 15,345$ & $10,700,000$ & $12 \%$ \\
\hline Indiana & 275 & $\$ 17,100,000$ & $\$ 17,758$ & $5,665,894$ & $8 \%$ \\
\hline Iowa & 77 & $\$ 14,500,000$ & $\$ 30,509$ & $2,952,751$ & $2 \%$ \\
\hline Kansas/Nebraska & 202 & $\$ 9,893,160$ & $\$ 16,648$ & $19,000,000$ & $5 \%$ \\
\hline Kentucky & 2,232 & $\$ 9,189,564$ & $\$ 11,518$ & $3,463,685$ & $7 \%$ \\
\hline Louisiana & 1,218 & $\$ 9,605,626$ & $\$ 12,060$ & $3,673,111$ & $32 \%$ \\
\hline Maryland & 248 & $\$ 10,100,000$ & $\$ 16,918$ & $3,931,059$ & $22 \%$ \\
\hline Michigan & 190 & $\$ 30,600,000$ & $\$ 18,720$ & $9,276,525$ & $13 \%$ \\
\hline Minnesota/Wiscon & 92 & $\$ 46,600,000$ & $\$ 30,395$ & $57,400,000$ & $4 \%$ \\
\hline Mississippi & 1,825 & $\$ 6,238,202$ & $\$ 10,245$ & $2,454,882$ & $40 \%$ \\
\hline Missouri & 1,798 & $\$ 11,900,000$ & $\$ 13,121$ & $4,786,754$ & $10 \%$ \\
\hline Montana & 98 & $\$ 4,646,119$ & $\$ 27,457$ & 924,037 & $0 \%$ \\
\hline Nevada & 95 & $\$ 7,813,864$ & $\$ 27,793$ & $1,826,086$ & $7 \%$ \\
\hline New England & 141 & $\$ 72,600,000$ & $\$ 37,146$ & $13,800,000$ & $1 \%$ \\
\hline New Mexico & 237 & $\$ 3,756,074$ & $\$ 11,490$ & $1,238,526$ & $2 \%$ \\
\hline New York & 215 & $\$ 94,200,000$ & $\$ 30,075$ & $18,600,000$ & $15 \%$ \\
\hline North Carolina & 3,353 & $\$ 16,800,000$ & $\$ 12,483$ & $5,961,804$ & $24 \%$ \\
\hline Ohio & 406 & $\$ 32,200,000$ & $\$ 17,239$ & $10,800,000$ & $10 \%$ \\
\hline Oklahoma & 1,328 & $\$ 7,118,536$ & $\$ 12,518$ & $2,868,963$ & $7 \%$ \\
\hline Oregon-Washingto & 135 & $\$ 3,235,087$ & $\$ 4,878$ & $14,500,000$ & $1 \%$ \\
\hline Pennsylvania & 158 & $\$ 55,900,000$ & $\$ 25,793$ & $12,200,000$ & $10 \%$ \\
\hline South Carolina & 1,579 & $\$ 8,655,877$ & $\$ 11,460$ & $3,047,249$ & $33 \%$ \\
\hline Tennessee & 2,639 & $\$ 12,400,000$ & $\$ 12,421$ & $4,417,496$ & $16 \%$ \\
\hline Texas & 4,047 & $\$ 37,800,000$ & $\$ 13,393$ & $14,300,000$ & $12 \%$ \\
\hline Utah-Idaho & 91 & $\$ 9,512,277$ & $\$ 18,834$ & $15,700,000$ & $1 \%$ \\
\hline Virginia & 1,418 & $\$ 12,300,000$ & $\$ 15,457$ & $5,228,534$ & $20 \%$ \\
\hline West Virginia & 107 & $\$ 7,947,576$ & $\$ 17,716$ & $1,838,747$ & $3 \%$ \\
\hline Wyoming & 67 & $\$ 2,121,870$ & $\$ 31,783$ & 513,947 & $1 \%$ \\
\hline Total & 1,165 & $\$ 18,200,000$ & $\$ 16,352$ & $7,140,341$ & $15 \%$ \\
\hline
\end{tabular}

Source: BEA Regional Economic Accounts 


\begin{tabular}{rrrrrr}
\hline \multicolumn{7}{l}{ Table 5: Summary of model covariates by year } & & & \\
\hline YEAR & CHURCHES* & TRANSFERS* & $\begin{array}{c}\text { PER CAPITA } \\
\text { INCOME }\end{array}$ & $\begin{array}{c}\text { STATE } \\
\text { POPULATION }\end{array}$ & $\begin{array}{c}\text { RACE( Percent } \\
\text { Black) }\end{array}$ \\
\hline & & & & & \\
1935 & 24,613 & $\$ 522,534$ & $\$ 359$ & $2,630,211$ & $22 \%$ \\
1940 & 25,018 & $\$ 736,323$ & $\$ 457$ & $2,756,316$ & $21 \%$ \\
1945 & 25,969 & $\$ 2,364,886$ & $\$ 1,055$ & $3,141,800$ & $20 \%$ \\
1950 & 27,072 & $\$ 6,573,122$ & $\$ 1,331$ & $3,331,455$ & $18 \%$ \\
1955 & 29,594 & $\$ 8,281,214$ & $\$ 1,766$ & $3,725,875$ & $17 \%$ \\
1960 & 32,245 & $\$ 15,700,000$ & $\$ 2,144$ & $4,507,155$ & $15 \%$ \\
1965 & 33,487 & $\$ 22,500,000$ & $\$ 2,705$ & $4,919,763$ & $15 \%$ \\
1970 & 34,795 & $\$ 47,400,000$ & $\$ 3,924$ & $5,220,459$ & $14 \%$ \\
1975 & 34,622 & $\$ 140,000,000$ & $\$ 6,116$ & $6,246,007$ & $14 \%$ \\
1980 & 35,030 & $\$ 235,000,000$ & $\$ 9,788$ & $7,099,695$ & $14 \%$ \\
1985 & 36,145 & $\$ 400,000,000$ & $\$ 14,054$ & $8,518,447$ & $13 \%$ \\
1990 & 37,376 & $\$ 555,000,000$ & $\$ 18,485$ & $8,235,548$ & $13 \%$ \\
1995 & - & $\$ 820,000,000$ & $\$ 22,534$ & $8,868,091$ & $13 \%$ \\
2000 & - & $\$ 22,200,000$ & $\$ 28,804$ & $9,508,640$ & $13 \%$ \\
2005 & 37,676 & $\$ 1,010,000,000$ & $\$ 34,383$ & $10,100,000$ & $13 \%$ \\
2010 & 44,625 & $\$ 1,410,000,000$ & $\$ 38,942$ & $10,700,000$ & $13 \%$ \\
2015 & 45,166 & $\$ 2,160,000,000$ & $\$ 46,096$ & $11,300,000$ & $13 \%$ \\
\hline
\end{tabular}

* indicates total sum by year, other columns are state-year averages 


\begin{tabular}{rr}
\hline \multicolumn{1}{l}{ Table 6: Year of Blue Laws Repeal by State } \\
\hline State & \multicolumn{2}{c}{ Year of Appeal } \\
\hline FL & 1969 \\
IA & 1955 \\
IN & 1977 \\
KS & 1965 \\
MN & 1985 \\
ND & 1991 \\
OH & 1973 \\
PN & 1978 \\
SC & 1985 \\
SD & 1977 \\
TN & 1981 \\
TX & 1985 \\
UT & 1973 \\
VT & 1982 \\
VI & 1975 \\
WA & 1966 \\
\hline
\end{tabular}


Table 7: Religious Cost by Year (State Pop (in 10,000) divided by \# of SBC Churches)

\begin{tabular}{cccc}
\hline Year & \multicolumn{2}{c}{ Mean } & \multicolumn{2}{c}{ Std. Dev. } & \\
\hline 1935 & 0.45 & 0.68 & 18 \\
1940 & 0.62 & 0.91 & 19 \\
1945 & 1.12 & 2.50 & 20 \\
1950 & 1.13 & 1.67 & 22 \\
1955 & 1.46 & 3.71 & 23 \\
1960 & 1.68 & 2.70 & 28 \\
1965 & 1.31 & 1.93 & 28 \\
1970 & 1.62 & 2.74 & 29 \\
1975 & 2.61 & 4.86 & 31 \\
1980 & 2.63 & 4.24 & 32 \\
1985 & 9.57 & 29.76 & 35 \\
1990 & 3.84 & 8.80 & 37 \\
2005 & 4.75 & 11.53 & 37 \\
2010 & 3.68 & 9.77 & 36 \\
2015 & 3.73 & 9.93 & 37 \\
\hline
\end{tabular}




\begin{tabular}{|c|c|c|c|c|c|c|}
\hline Variable & Description & Obs & Mean & Std. Dev. & Min & Max \\
\hline Per Church LM & LM contributions per church & 431 & $\$ 1,618$ & $\$ 1,225$ & $\$ 0$ & $\$ 7,712$ \\
\hline LM_real & by state real LM contributions & 512 & $\$ 2,398,153$ & $\$ 3,823,920$ & $\$ 0$ & $\$ 21,400,000$ \\
\hline Per Church CP & CP Contributions per church & 431 & $\$ 1,412$ & $\$ 961$ & $\$ 11$ & $\$ 4,832$ \\
\hline CP_real & by state real CP contributions & 512 & $\$ 2,028,244$ & $\$ 2,853,141$ & $\$ 0$ & $\$ 17,300,000$ \\
\hline Religious Cost & state population (in 10,000 ) per church & 432 & 3.1 & 10.7 & 0.1 & 138.7 \\
\hline Secular Cost & dummy for Blue Laws repeal by state & 157 & 0.6 & 0.5 & 0.0 & 1.0 \\
\hline Per Capita Income & Per Capita Income by State & 513 & $\$ 16,352$ & $\$ 15,491$ & $\$ 174$ & $\$ 73,302$ \\
\hline Government Transfers & Government Transfers by State & 513 & $\$ 18,200,000$ & $\$ 35,000,000$ & $\$ 6,238$ & $\$ 324,000,000$ \\
\hline Race & Percent Black by State & 513 & 0.1 & 0.1 & 0.0 & 0.7 \\
\hline
\end{tabular}

Notes:

LM indicates Lottie Moon Christmas Offerings. CP indicates church contributions to the Cooperative program. Both are in real USD. 


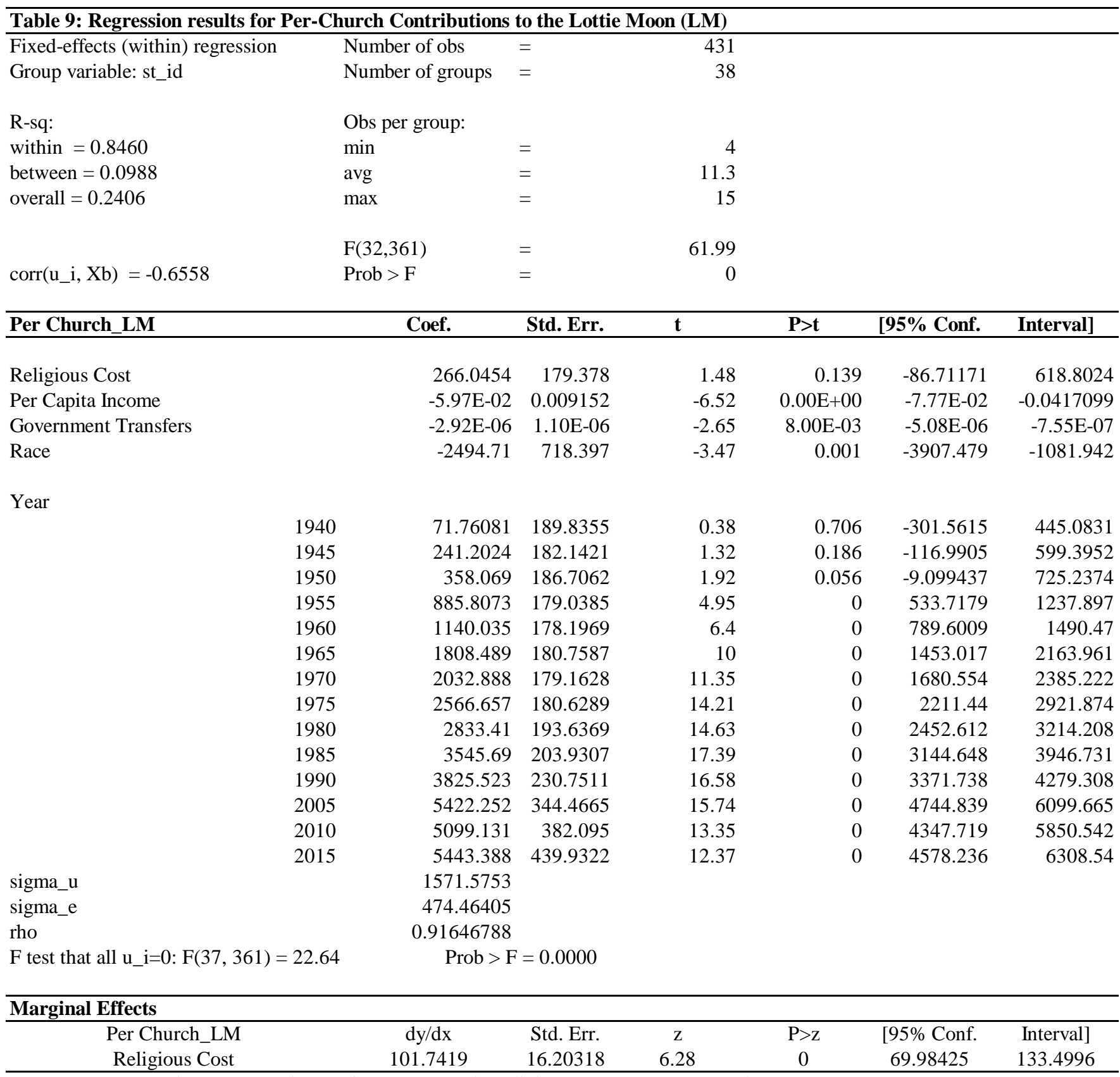

Notes: For presentation purposes, interaction terms year by religious costs are not reported. 


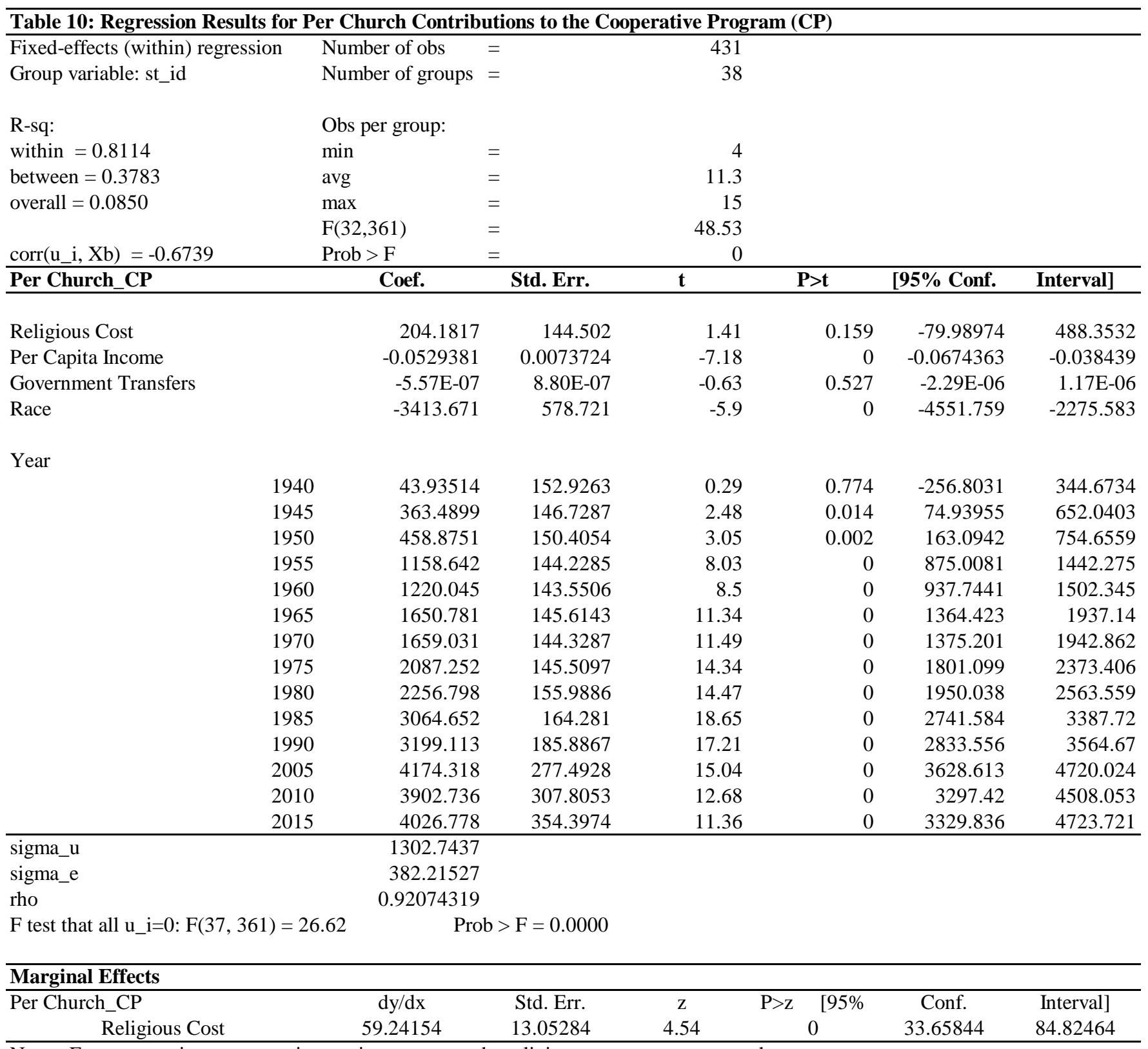

Notes: For presentation purposes, interaction terms year by religious costs are not reported. 


\begin{tabular}{|c|c|c|c|c|c|c|}
\hline & Coef. & Std. Err. & $\mathbf{t}$ & $\mathbf{P}>\mathbf{t}$ & [95\% Conf. & Interval] \\
\hline \multirow[t]{3}{*}{ Secular Cost } & 1271.55 & 346.37 & 3.67 & 0.00 & 584.84 & 1958.26 \\
\hline & $\mathrm{dy} / \mathrm{dx}$ & Std. Err. & $\mathbf{t}$ & $\mathbf{P}>\mathbf{t}$ & [95\% Conf. & Interval] \\
\hline & Std. & Err. & $\mathrm{t}$ & $\mathrm{P}>\mathrm{t}$ & {$[95 \%$ Conf. } & Interval] \\
\hline Florida & 1271.550 & 346.371 & 3.67 & 0.000 & 584.837 & 1958.264 \\
\hline Indiana & 552.0756 & 350.0873 & 1.58 & 0.118 & -142.0064 & 1246.158 \\
\hline Iowa & & (not & & & & \\
\hline Kansas/Nebraska & 708.237 & 359.648 & 1.97 & 0.052 & -4.800 & 1421.274 \\
\hline Ohio & 1392.225 & 337.5731 & 4.12 & 0 & 722.9537 & 2061.497 \\
\hline Oregon-Washington & 305.541 & 571.786 & 0.53 & 0.594 & -828.081 & 1439.163 \\
\hline Pennsylvania & 52.1734 & 561.9395 & 0.09 & 0.926 & -1061.926 & 1166.273 \\
\hline South Carolina & -185.378 & 356.097 & -0.52 & 0.604 & -891.375 & 520.620 \\
\hline Tennessee & 1071.1 & 308.9897 & 3.47 & 0.001 & 458.4983 & 1683.702 \\
\hline Texas & 1792.808 & 331.704 & 5.4 & 0.000 & 1135.173 & 2450.443 \\
\hline Utah-Idaho & 4.727707 & 556.212 & 0.01 & 0.993 & -1098.017 & 1107.472 \\
\hline Virginia & -158.634 & 310.033 & -0.510 & 0.610 & -773.304 & 456.036 \\
\hline
\end{tabular}




\begin{tabular}{|c|c|c|c|c|c|c|}
\hline & Coef. & Std. Err. & $\mathbf{t}$ & $\mathbf{P}>\mathbf{t}$ & {$[95 \%$ Conf. } & Interval] \\
\hline \multirow[t]{2}{*}{ Secular Cost } & 746.74 & 423.60 & 1.76 & 0.08 & -93.09 & 1586.57 \\
\hline & $d y / d x$ & Std. Err. & $\mathbf{t}$ & $\mathbf{P}>t$ & {$[95 \%$ Conf. } & Interval] \\
\hline Florida & 746.7392 & 423.5988 & 1.76 & 0.081 & -93.08666 & 1586.565 \\
\hline Indiana & 252.776 & 428.144 & 0.590 & 0.556 & -596.062 & 1101.614 \\
\hline Iowa & & (not & ble) & & & \\
\hline Kansas/Nebraska & 950.810 & 439.837 & 2.160 & 0.033 & 78.791 & 1822.829 \\
\hline Ohio & 1007.819 & 412.8399 & 2.44 & 0.016 & 189.3235 & 1826.314 \\
\hline Oregon-Washington & 492.989 & 699.275 & 0.700 & 0.482 & -893.391 & 1879.368 \\
\hline Pennsylvania & -514.3508 & 687.2321 & -0.75 & 0.456 & -1876.855 & 848.1536 \\
\hline South Carolina & 32.274 & 435.494 & 0.070 & 0.941 & -831.135 & 895.684 \\
\hline Tennessee & 1540.669 & 377.8834 & 4.08 & 0 & 791.4779 & 2289.859 \\
\hline Texas & 1789.164 & 405.662 & 4.410 & 0.000 & 984.899 & 2593.428 \\
\hline Utah-Idaho & -168.3599 & 680.2276 & -0.25 & 0.805 & -1516.977 & 1180.257 \\
\hline Virginia & 561.406 & 379.159 & 1.480 & 0.142 & -190.313 & 1313.126 \\
\hline
\end{tabular}




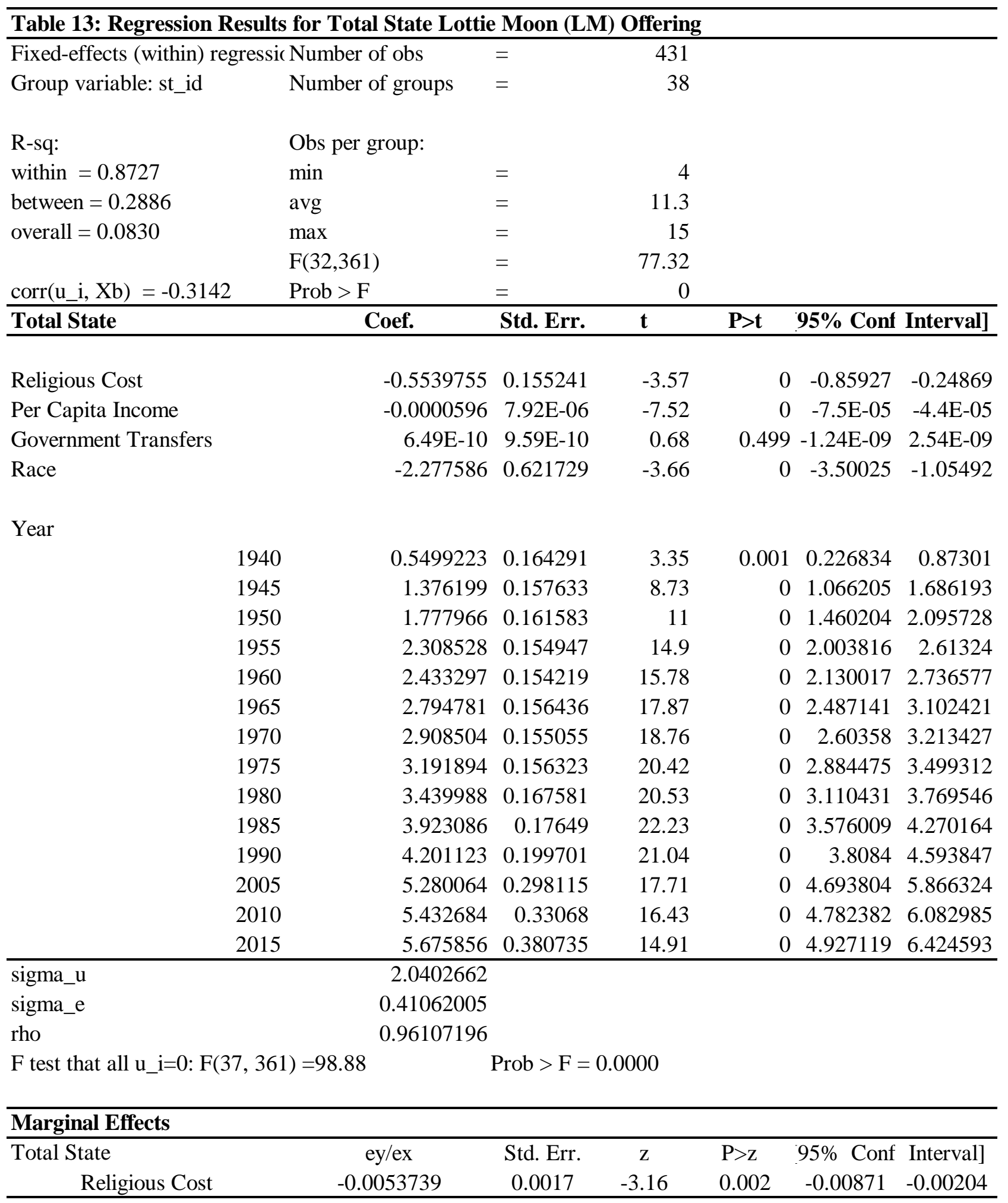

Notes: For presentation purposes, interaction terms year by religious costs are not reported. 


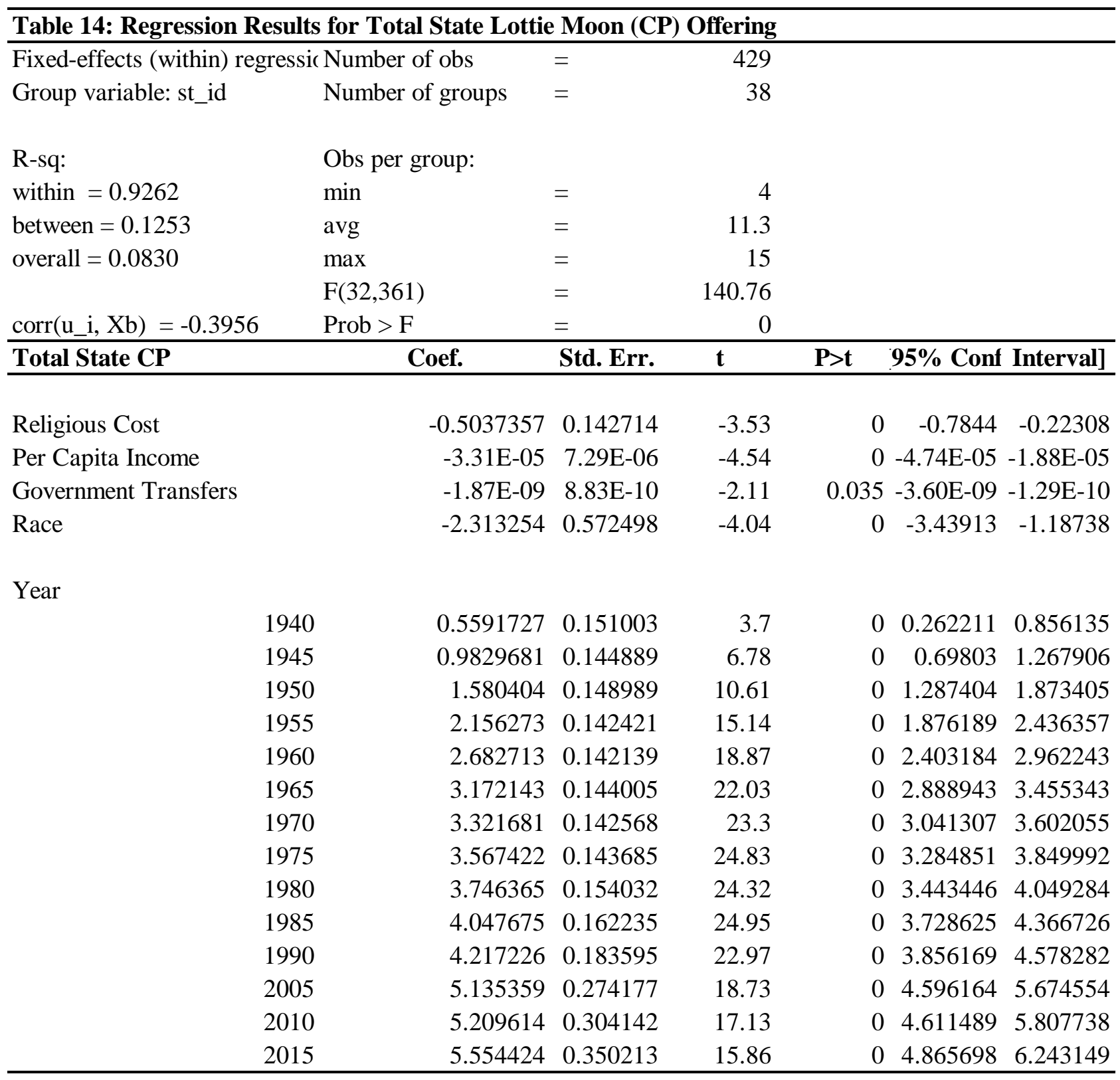

$\begin{array}{lr}\text { sigma_u } & 2.1273473 \\ \text { sigma_e } & 0.37740842 \\ \text { rho } & 0.96948677\end{array}$

\begin{tabular}{|c|c|c|c|c|c|}
\hline Marginal Effects & & & & & \\
\hline Total State CP & ey/ex & Std. Err. & $\mathrm{z}$ & $\mathrm{P}>\mathrm{Z}$ & $95 \%$ Conf Interval] \\
\hline Religious Cost & -0.0085351 & 0.001967 & -4.34 & 0 & $-0.01239-0.00468$ \\
\hline
\end{tabular}

Notes: For presentation purposes, interaction terms year by religious costs are not reported. 
Table 15: Marginal Effects for Total Contributions by REPEAL

\begin{tabular}{|c|c|c|c|c|c|c|}
\hline & eyex & Std. Err. & $\mathbf{t}$ & $\mathbf{P}>\mathbf{t}$ & {$[95 \%$ Conf. } & Interval] \\
\hline \multicolumn{7}{|l|}{$\log _{-} \mathrm{CP}$} \\
\hline Secular Cost & -0.46 & 0.51 & -0.89 & 0.38 & -1.47 & 0.56 \\
\hline \multicolumn{7}{|l|}{ log_LM } \\
\hline Secular Cost & 0.06 & 0.18 & 0.32 & 0.75 & -0.29 & 0.40 \\
\hline
\end{tabular}




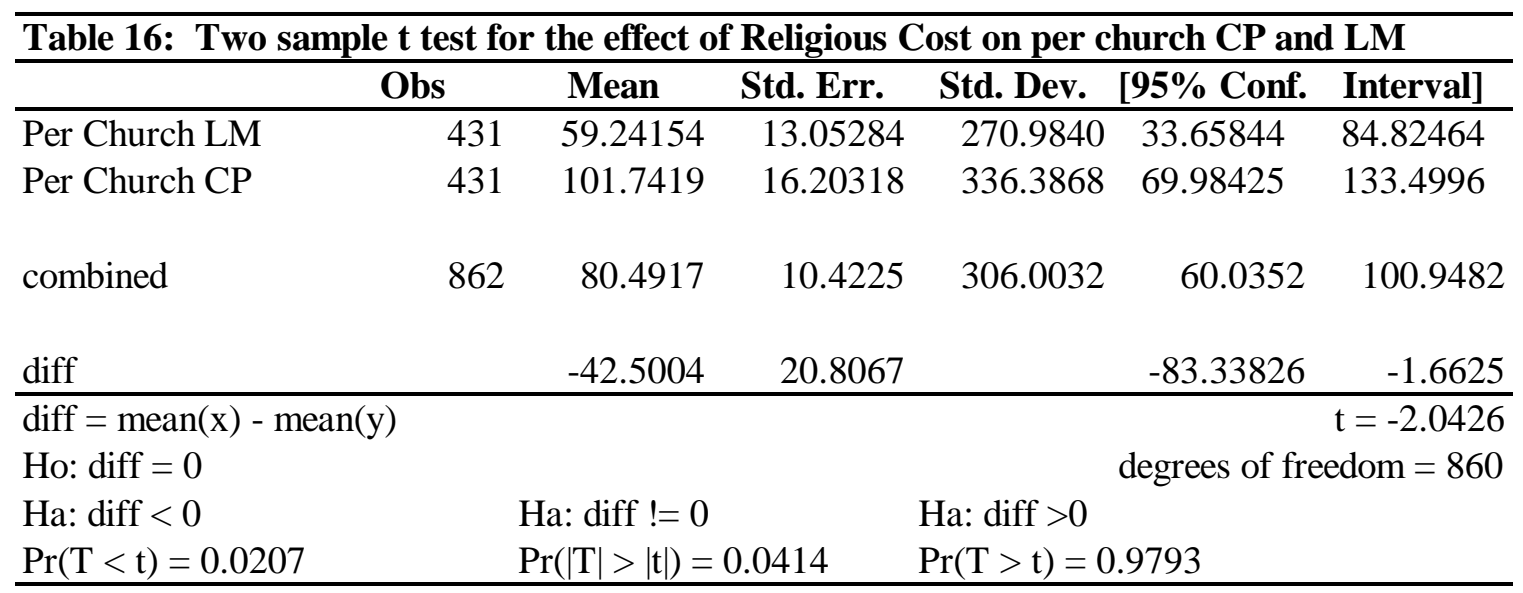


Table 17: Two sample $t$ test for the effect of REPEAL on Per Church CP and Per Church LM

\begin{tabular}{lllllll}
\hline Obs & Mean & Std. Err. & Std. Dev. & [95\% Conf. & Interval] \\
\hline
\end{tabular}

\begin{tabular}{lllllll}
\hline Per Church LM & 128 & 746.74 & 423.60 & 4792.4733 & -93.09 & 1586.57
\end{tabular}

\begin{tabular}{lllllll} 
Per Church CP & 128 & 1271.55 & 346.37 & 3918.7349 & 414.9430 & 871.6012 \\
\hline
\end{tabular}

\begin{tabular}{|c|c|c|c|c|c|c|}
\hline combined & 256 & 1009.1450 & 273.5482 & 4376.7710 & 470.4433 & 1547.8460 \\
\hline diff & & 524.8108 & 547.1823 & & -552.7813 & 1602.4030 \\
\hline
\end{tabular}

Ho: diff $=0 \quad$ degrees of freedom $=254$

Ha: diff $<0 \quad$ Ha: diff $!=0 \quad$ Ha: diff $>0$

$\operatorname{Pr}(\mathrm{T}<\mathrm{t})=0.8308 \quad \operatorname{Pr}(|\mathrm{T}|>|\mathrm{t}|)=0.3384 \quad \operatorname{Pr}(\mathrm{T}>\mathrm{t})=0.1692$ 